\section{Check for updates}

Cite this: Org. Biomol. Chem., 2018, 16, 3970

Received 19th April 2018,

Accepted 4th May 2018

DOI: $10.1039 / c 80 b 00924 d$

rsc.li/obc

\title{
Synthesis of fused tricyclic systems by thermal Cope rearrangement of furan-substituted vinyl cyclopropanes $\uparrow$
}

\author{
Verena Klaus, Stéphane Wittmann, Hans M. Senn (iD and J. Stephen Clark (D) *
}

A novel method for the stereoselective construction of hexahydroazuleno[4,5-b]furans from simple precursors has been developed. The route involves the use of our recently developed Brønsted acid catalysed cyclisation reaction of acyclic ynenones to prepare fused 1-furanyl-2-alkenylcyclopropanes that undergo highly stereoselective thermal Cope rearrangement to produce fused tricyclic products. Substrates possessing an E-alkene undergo smooth Cope rearrangement at $40{ }^{\circ} \mathrm{C}$, whereas the corresponding $Z$-isomers do not react at this temperature. Computational studies have been performed to explain the difference in behaviour of the $E$ - and $Z$-isomers in the Cope rearrangement reaction. The hexahydroazuleno[4,5-b]furans produced by Cope rearrangement have potential as advanced intermediates for the synthesis of members of the guaianolide family of natural products.

\section{Introduction}

Furans and benzofurans occur frequently as sub-units in pharmaceuticals and bioactive natural products. ${ }^{1,2}$ In many natural products, a furan or benzofuran is embedded in a polycyclic array or a macrocycle and is fused to one or more rings. An interesting and synthetically alluring group of furan-containing natural products comprises compounds that possess a furan or benzofuran fused to a seven-membered ring. Examples include myrrhterpenoid $\mathrm{H},{ }^{3}$ frondosin $\mathrm{B}^{4}$ and liphagal, ${ }^{5}$ which have been popular targets in recent years and have been shown to possess biological activities such as neuroprotective activity, ${ }^{3}$ binding to interlukin-8 receptors ${ }^{4}$ and inhibition of various kinases ${ }^{4,5}$ (Fig. 1).

We have recently embarked on a programme directed toward the development of new methods for the concise and efficient synthesis of highly functionalised furans. As part of this programme, we wished to explore whether polycyclic systems containing the cyclohepta $[b]$ furan unit could be synthesised from the cyclopropyl-substituted furans prepared by use of our recently-discovered stereoselective Brønsted acid catalysed cascade reaction (Scheme 1). ${ }^{6}$ In previous work, we have shown that treatment of the structurally diverse ynenediones 1

WestCHEM, School of Chemistry, Joseph Black Building, University of Glasgow, University Avenue, Glasgow G12 8QQ, UK. E-mail: stephen.clark@glasgow.ac.uk; Tel: +44 (o)1413306296

$\dagger$ Electronic supplementary information (ESI) available: Copies of NMR spectra $\left({ }^{1} \mathrm{H}\right.$ and ${ }^{13} \mathrm{C}$ ) for compounds $20-33$ and $35-37$ plus details of computational studies. See DOI: 10.1039/c8ob00924d with chloroacetic acid results in intramolecular cyclisation to produce the tricyclic products 2 in which a trisubstituted furan is connected to a cyclopropyl substituent at the $\alpha$ position. The reaction is proposed to occur by carbonyl group protonation, and nucleophilic attack of the oxygen onto the central carbon of the putative allenyl intermediate to produce a carbene that reacts with the pendent alkene to form a cyclopropane. ${ }^{6}$

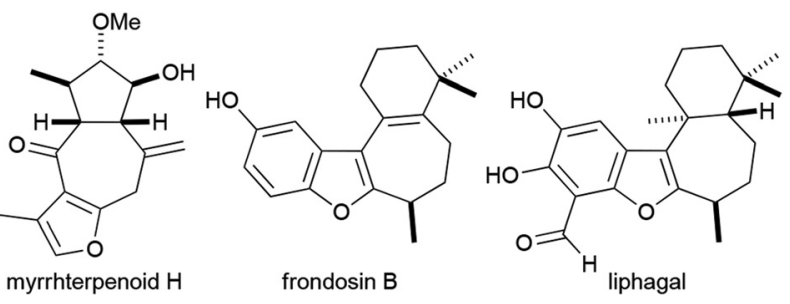

Fig. 1 Examples of some bioactive natural products that possess a furan or benzofuran fused to a seven-membered ring.

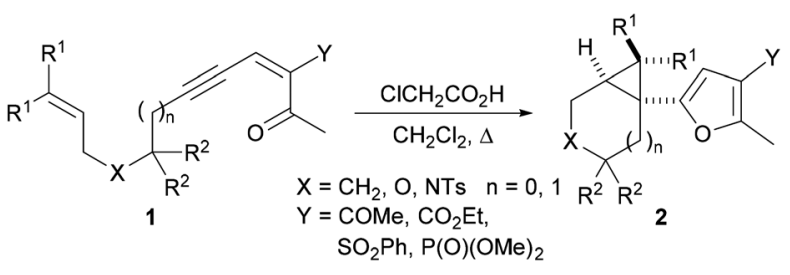

Scheme 1 Synthesis of cyclopropyl-substituted furans by Brønsted acid mediated intramolecular cascade reactions. 

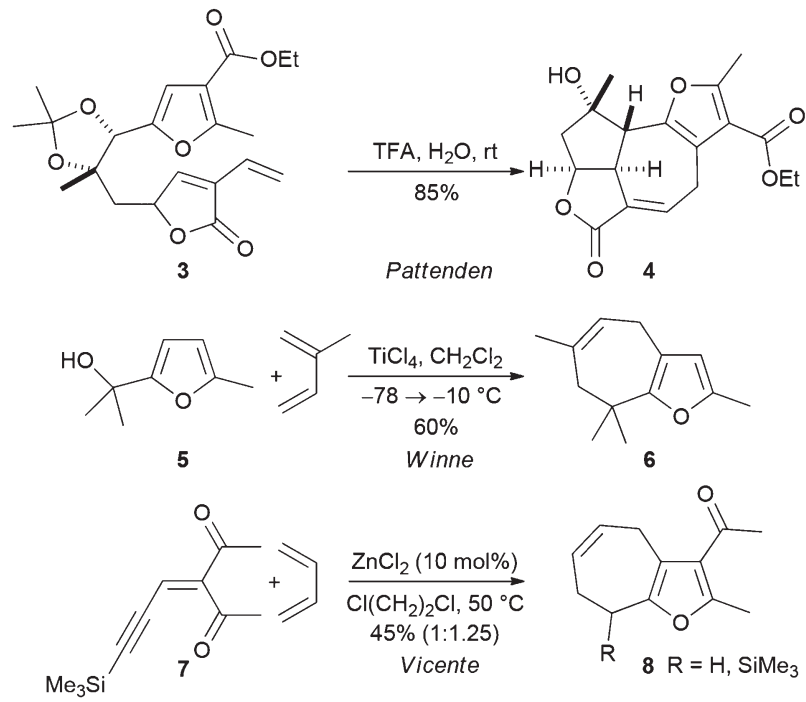

Scheme 2 Preparation of partially reduced cyclohepta[b]furans by use of $[4+3]$ cycloaddition reactions.

Cyclohepta $[b]$ furans can be prepared from simple furfuryl alcohols by formal $[4+3]$ cycloadditions reactions (Scheme 2). Pattenden and Winne have shown that the furan-containing diene 3 undergoes an intramolecular acid mediated reaction to produce the fused lactone $\mathbf{4}$, a tetracyclic compound that comprises most of the core structure of the marine diterpene rameswaralide. ${ }^{7}$ Winne and co-workers have developed an intermolecular variant of the reaction in which a Lewis acid catalysed reaction of a furfuryl alcohol with a simple diene delivers a cyclohepta $[b]$ furan. ${ }^{8}$ For example, the reaction was used to convert the furfuryl alcohol $\mathbf{5}$ into the cyclohepta[$[b]$ furan 6 in reasonable yield (Scheme 2).

The groups of Liang and Vicente have reported a one-pot method for the synthesis of fused cyclohepta $[b]$ furans from acyclic precursors by Lewis acid mediated cyclisation of an ynenedione in the presence of a diene (Scheme 2). ${ }^{9,10}$ For example, treatment of the substrate 7 with zinc(II) chloride in the presence of butadiene, was found to deliver a mixture of the silylated and desilylated products $8 .^{10}$ It was proposed that the products result from a formal $[4+3]$ cycloaddition reaction, but cyclopropane formation and subsequent Cope rearrangement cannot be ruled out in these cases.

The successful preparation of highly functionalised cyclopropyl-substituted furans by use of our Brønsted acid promoted cyclisation reaction (Scheme 1) prompted us to explore whether these compounds could be rearranged to give fused tricyclic compounds containing an embedded furan. Our general approach to the synthesis of fused tricyclic compounds is depicted in Scheme 3. In the proposed reaction sequence, Brønsted acid promoted cyclisation of an acyclic ynenone 9, which possesses a tethered diene, would be used to produce a vinyl cyclopropane 10. Subsequent Cope rearrangement should deliver the fused tricyclic triene $\mathbf{1 1}$ and re-aromatization would result in formation of the furan-containing tricyclic

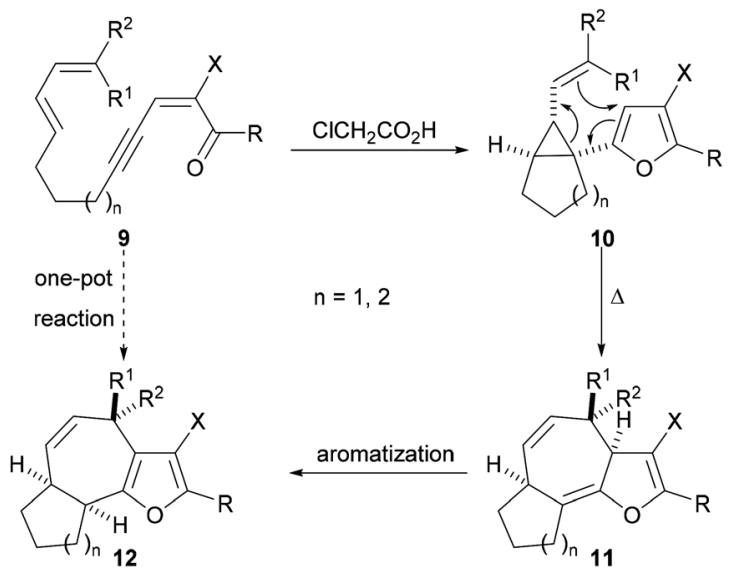

Scheme 3 Proposed conversion of acyclic diene-tethered ynenones into highly functionalised fused tricyclic systems.

product 12. It was anticipated that, under appropriate reaction conditions, the acyclic precursor 9 could be transformed directly into the fused tricyclic product $\mathbf{1 2}$ in a one-pot fashion with the creation of three rings, three bonds and three stereogenic centres in a single operation.

There are just three examples of the thermal Cope rearrangement of 1-furanyl-2-vinylcyclopropanes. ${ }^{11,12}$ In 1980, Maas and Hummel described the rearrangement of the very simple substrates $\mathbf{1 3 a}$ and $\mathbf{1 3 b}$ to give the 3a,7-dihydro- $4 \mathrm{H}^{-}$ cyclohepta $[b]$ furans $\mathbf{1 4 a}$ and $\mathbf{1 4 b}$ in low yield by heating them in toluene or deuterated benzene (Scheme 4). ${ }^{11}$ Aromatized 7,8-dihydro- $4 H$-cyclohepta[ $b]$ furans $\mathbf{1 5 a}$ and $\mathbf{1 5 b}$ were obtained when toluene solutions of the substrates were heated at higher temperatures in a sealed tube. The only other example of the reaction is an unusual one published by Barluenga and coworkers, in which the unstable fused tricyclic lactone $\mathbf{1 7}$ was prepared by thermal rearrangement of the lactone-containing
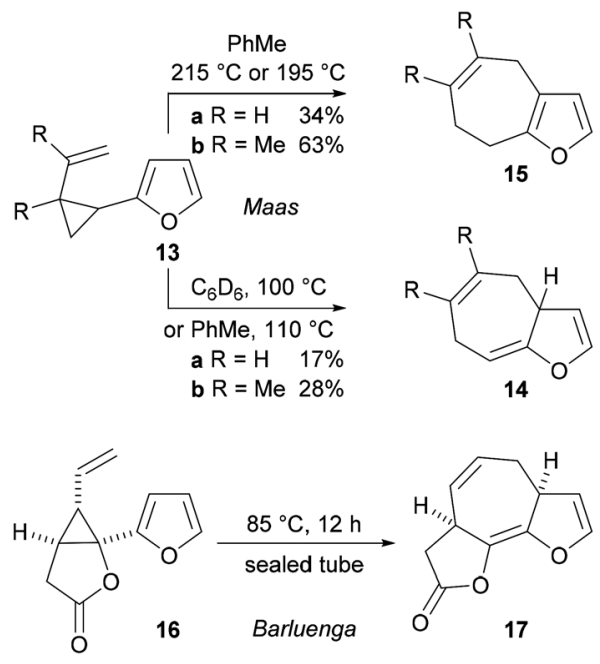

Scheme 4 Previous examples of Cope rearrangement reactions of vinylcyclopropane-substituted furans. 
vinyl cyclopropane 16 at $85{ }^{\circ} \mathrm{C} .{ }^{12}$ A systematic study of the scope of the thermal Cope rearrangement of 1-furanyl-2-vinylcyclopropanes has not been published and there are no examples of the use of the reaction to prepare more complex fused polycyclic systems from cyclopropyl-substituted furans that possess additional rings.

\section{Results and discussion}

\section{Exploration of the Cope rearrangement reactions of vinylcyclopropane-substituted furans}

Our studies commenced with the synthesis of the aldehyde 23, the key intermediate required for the preparation of the Cope rearrangement precursors (Scheme 5). The known alcohol $\mathbf{1 8}^{\mathbf{1 3}}$ was $O$-protected and the trimethylsilyl group was removed. The resulting terminal alkyne was then formylated to give the propargylic aldehyde 19. Knoevenagel condensation of the aldehyde 19 with acetylacetone produced the ynenedione 20 and this compound was then subjected to an acid-catalysed cascade cyclisation reaction to give the furan $\mathbf{2 1}$ in excellent yield and with high diastereoselectivity $(>98: 2)$. Acid-mediated cleavage of the $t$-butyldimethysilyl ether and oxidation of the resulting alcohol 22 with the Dess-Martin periodinane afforded the required aldehyde $\mathbf{2 3}$ in excellent yield.

The substrates used in our study of the Cope rearrangement reaction were obtained by alkylidenation of the aldehyde 23 using a Wittig reaction (entries 1-4, Table 1) or a JuliaKocienski reaction (entries 5-7, Table 1). The alkenes 24-27

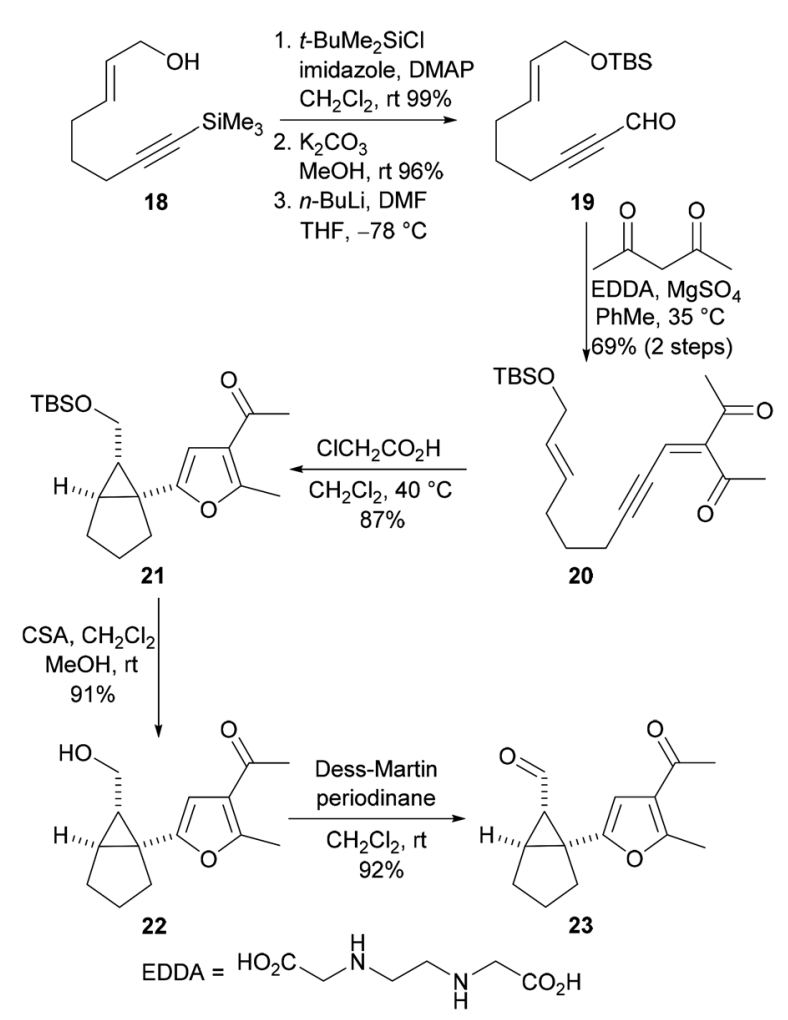

Scheme 5 Synthesis of the tricyclic aldehyde 23.
Table 1 Conversion of the tricyclic aldehyde 23 into the Cope rearrangement precursors $24-27$

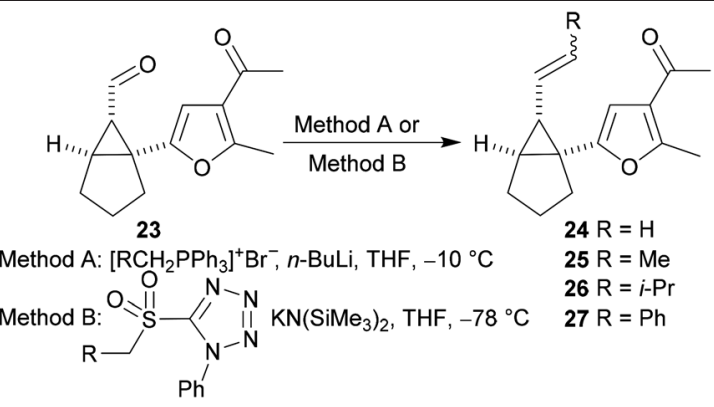

\begin{tabular}{llllll}
\hline Entry & Method & $\mathrm{R}$ & $E: Z$ ratio $^{a}$ & Product & Yield $^{b}(\%)$ \\
\hline 1 & A & $\mathrm{H}$ & - & $\mathbf{2 4}$ & 81 \\
2 & A & $\mathrm{Me}$ & $27: 73$ & $\mathbf{2 5}$ & 79 \\
3 & $\mathbf{A}$ & $\mathrm{i}-\mathrm{Pr}$ & $12: 88$ & $\mathbf{2 6}$ & 30 \\
4 & $\mathbf{A}$ & $\mathrm{Ph}$ & $47: 53$ & $\mathbf{2 7}$ & 91 \\
5 & B & $\mathrm{Me}$ & $87: 13$ & $\mathbf{2 5}$ & 51 \\
6 & B & i-Pr & $87: 13$ & $\mathbf{2 6}$ & 17 \\
7 & B & $\mathrm{Ph}$ & $70: 30$ & $\mathbf{2 7}$ & 41
\end{tabular}

${ }^{a}$ Ratio determined by ${ }^{1} \mathrm{H}$ NMR analysis. ${ }^{b}$ Yield of isolated product.

were obtained with variable yields and with $E: Z$ ratios that were dependent on the alkylidenation reaction that was employed.

Rearrangement of the 1-furanyl-2-alkenylcyclopropane $\mathbf{2 4}$ was explored first. When a solution of the substrate was heated in toluene at reflux for 1 hour, the fused tricyclic product 28 was obtained as single diastereoisomer in $36 \%$ yield (entry 1 , Table 2). Subsequent reactions were performed at lower temp-

Table 2 Cope rearrangement of the 1-furanyl-2-alkenylcyclopropanes 24-27

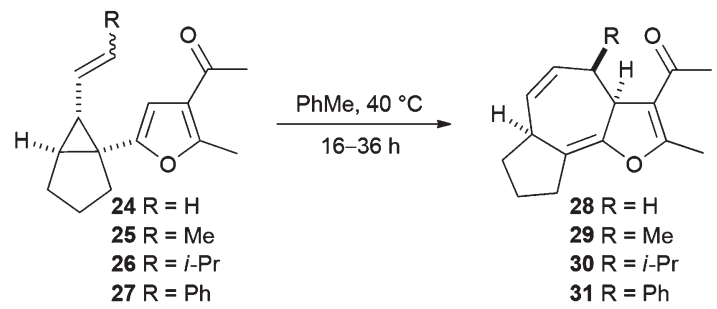

\begin{tabular}{llllll}
\hline Entry & $\begin{array}{l}\text { Substrate } \\
(E: Z \text { ratio })^{a}\end{array}$ & Time (h) & Product & $\begin{array}{l}\text { Yield }^{b} \\
(\%)\end{array}$ & $\begin{array}{l}\text { Recovered } \\
\mathbf{2 4 - 2 7}(\%)\end{array}$ \\
\hline $1^{c}$ & $\mathbf{2 4}$ & 1 & $\mathbf{2 8}$ & 36 & - \\
2 & $\mathbf{2 4}$ & 16 & $\mathbf{2 8}$ & 63 & - \\
3 & $\mathbf{2 5}(27: 73)$ & 18 & $\mathbf{2 9}$ & 23 & $40^{d}$ \\
4 & $\mathbf{2 5}(87: 13)$ & 24 & $\mathbf{2 9}$ & 50 & $50^{e}$ \\
5 & $\mathbf{2 6}(12: 88)$ & 36 & $\mathbf{3 0}$ & - & - \\
6 & $\mathbf{2 6}(87: 13)$ & 36 & $\mathbf{3 0}$ & 20 & $80^{f}$ \\
7 & $\mathbf{2 7}(47: 53)$ & 18 & $\mathbf{3 1}$ & 43 & $23^{d}$ \\
8 & $27(70: 30)$ & 24 & $\mathbf{3 1}$ & 48 & $28^{g}$
\end{tabular}

${ }^{a}$ Ratio determined by ${ }^{1} \mathrm{H}$ NMR analysis. ${ }^{b}$ Yields of isolated compounds. ${ }^{c}$ Reaction performed at $110{ }^{\circ} \mathrm{C} .{ }^{d}$ Only the $Z$ isomer was recovered. ${ }^{e} 74: 26 E: Z$ mixture of 25 recovered. ${ }^{f} 85: 15 E: Z$ mixture of 26 recovered. ${ }^{g} 12: 88 E: Z$ mixture of 27 recovered. 
eratures, which resulted in reduced reaction rates and extended reaction times, but delivered higher yields of the product. The highest yield (63\%) of the tricyclic product 28 was obtained when the reaction was performed in toluene at $40{ }^{\circ} \mathrm{C}$ (entry 2, Table 2). Inferior yields of this compound were obtained when rearrangement reactions performed in either THF or dichloromethane at $40{ }^{\circ} \mathrm{C}$. Aromatisation to form the furan system did not occur at this reaction temperature.

The Cope rearrangement reactions of substrates 25-27, which contain a non-terminal alkene, were then investigated (Table 2). The substrates - prepared and used as E/Z-mixtures - were dissolved in toluene and heated at $40{ }^{\circ} \mathrm{C}$. Cope rearrangement of substrate $25(27: 73, E: Z)$, prepared by Wittig olefination, resulted in complete consumption of $\boldsymbol{E}-\mathbf{2 5}$ in $18 \mathrm{~h}$ to give the tricyclic product 29 in $23 \%$ yield; $\$$ unreacted Z-25 was recovered (40\% mass recovery) and the product arising from rearrangement of this isomer was not observed (entry 3, Table 2). The substrate 25 (87:13, E:Z) prepared by Julia-Kocienski olefination underwent rearrangement to give the tricyclic product 29 in $50 \%$ yield and recovered starting material, enriched in $Z-25$ (72:28, $E: Z)$, was recovered (50\% mass recovery) (entry 4 , Table 2 ). Rearrangement of the substrate 26 bearing a bulky isopropyl group was low yielding. Attempted rearrangement of a sample of the substrate 26 in which the $Z$ isomer predominated $(12: 88, E: Z)$ failed to deliver the expected product and only starting material was recovered (entry 5, Table 2). The tricyclic rearrangement product 30 was obtained in $20 \%$ yield when substrate enriched in the $E$ isomer $(87: 13, E: Z)$ was employed as the substrate and all of the unreacted starting material 26 (85:15, $E: Z)$ was recovered after $36 \mathrm{~h}$ (entry 6, Table 2). The phenyl-substituted substrate 27 also underwent Cope rearrangement at $40{ }^{\circ} \mathrm{C}$. A sample of the substrate 27 containing approximately equal amounts of both alkene isomers $(47: 53, E: Z)$ rearranged to give the cycloheptadiene 31 in $43 \%$ yield and unreacted isomer Z-27 was recovered without any evidence of Cope rearrangement of this isomer (entry 7, Table 2). When a sample of the substrate 27 enriched in the $E$ isomer $(70: 30$, $E: Z$ ) was subjected to the rearrangement conditions, the yield of the fused tricyclic product 31 increased to $48 \%$ and unreacted starting material $(12: 88, E: Z)$ was recovered $(28 \%$ mass recovery) (entry 8 , Table 2 ).

The stereochemical relationship between the C-3a and C-4 stereocentres was confirmed by analysis of ${ }^{1} \mathrm{H}$ NMR data for the tricyclic ketone 31. Molecular modelling of the compounds 31 and $\boldsymbol{e p i - 3 1}$ revealed an expected dihedral angle (for $\mathrm{H}-\mathrm{C}-\mathrm{C}-$ $\mathrm{H})$ of $53^{\circ}$ at $\mathrm{C}-3 \mathrm{a}$ and $\mathrm{C}-4$ in the case of 31 and $175^{\circ}$ in the case of epi-31. This would imply a coupling constant of $4 \mathrm{~Hz}$ between the protons for ketone 31 and 11-12 Hz for C-4 dia-

$\$$ The relative configuration of the $3 \mathrm{a}, 4,6 \mathrm{a}, 7,8,9$-hexahydroazuleno[4,5- $b]$ furans 29-31 was confirmed by the magnitude of the coupling between the protons at C3 and C4, which was very small and indicative of a dihedral angle of approximately $90^{\circ}$. If the $\mathrm{C} 4$ epimers of the products $29-31$ had been obtained, this coupling would have been relatively large because the dihedral angle would have been close to $180^{\circ}$. stereomer (epi-31). ${ }^{14}$ The observed coupling between the protons is $3.7 \mathrm{~Hz}$, an observation which confirms that we obtained the expected diastereomer from the reaction of the substrate $\boldsymbol{E}$-27.

The results given in Table 2 reveal that increasing the size of the substituent $(\mathrm{R})$ results in a lower rate of reaction; in the case of isopropyl-substituted substrate $\boldsymbol{E}-\mathbf{2 6}$, the reaction was incomplete even after 36 hours. The second important observation is that the $Z$ isomers of substrates 25-27 are markedly less reactive than the corresponding $E$ isomers; products arising from Cope rearrangement of the $Z$ isomers were never isolated. This finding can be explained by consideration of the conformations leading to the respective transition states (Scheme 6). Cope rearrangement of cis-1,2-divinylcyclopropane is known to proceed through a boat-like transition state, resulting from an 'endo/endo' orientation of the alkenes in the diene precursor, to give $(Z, Z)-1,4$-cycloheptadiene. ${ }^{15}$ For the $E$ isomers in our study, the alkyl group lies over the furan in the transition state (TS-E) and in the substrate conformation leading to that transition state. In contrast, for the $Z$ isomers there is a highly unfavourable interaction between the alkene substituent $(\mathrm{R})$ and the ring-junction hydrogen $\left(\mathrm{H}_{\mathrm{a}}\right)$ as well as an eclipsing interaction between the alkene substituent (R) and the furan hydrogen $\left(\mathrm{H}_{\mathrm{b}}\right)$ in both the transition state (TS- $Z$ ) and the conformation leading to that transition state. This means that TS- $\boldsymbol{Z}$ is higher in energy than TS- $\boldsymbol{E}$ and so rearrangement reactions of $\mathbf{Z - 2 5 - 2 7}$ to give the products 29-31 will only occur at significantly higher temperatures than the rearrangement reactions of $\boldsymbol{E}-\mathbf{2 5}-\mathbf{2 7}$.

A complicating feature of the reaction is that Cope rearrangement is potentially reversible. Normally, Cope rearrangement of a divinylcyclopropane to produce a 1,4-cycloheptadiene would favour formation of the larger ring because of relief of ring-strain upon opening of the cyclopropane. However, in the case of our reactions, the aromaticity of the furan is sacrificed during rearrangement and fused tricyclic products that possess a high degree of conformational rigidity are generated. Consequently, it is possible that unfavourable enthalpic and entropic factors in the products 29-31 could counter-balance the energy gain from relief of ring-strain in
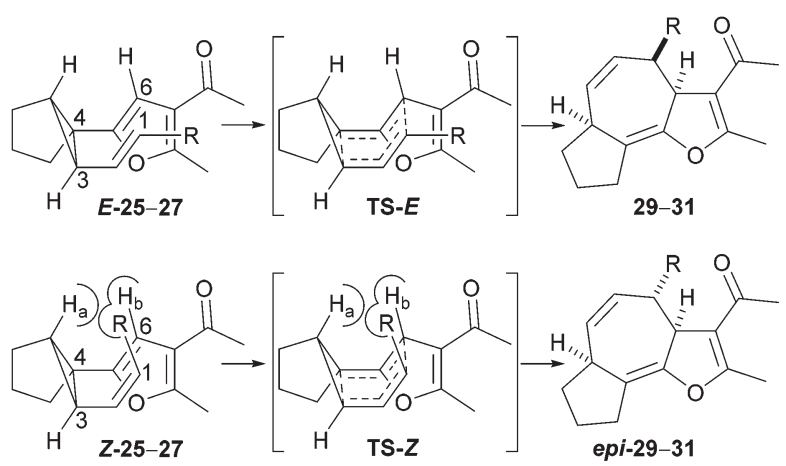

Scheme 6 Transition states for Cope rearrangement of $E$ and $Z$ alkenyl cyclopropane isomers. 
the substrates 25-27. It is even conceivable that reactions of the $Z$ isomers are disfavoured thermodynamically, which would account for our failure to isolate the products expected from Cope rearrangement of these substrates.

In all of the cases studied, the $3 \mathrm{a}, 4,6 \mathrm{a}, 7,8,9$-hexahydroazuleno[4,5- $b]$ furans 29-31 were obtained rather than the aromatized 4,6a,7,8,9,9a-hexahydroazuleno[4,5-b]furans (cf. compound 12 in Scheme 3). This is unsurprising, given that Maas and Hummel found that reaction temperatures of approximately $200{ }^{\circ} \mathrm{C}$ are required to aromatize the 3a,7-dihydro- $4 \mathrm{H}$ cyclohepta $[b]$ furans obtained from their Cope rearrangement reactions (Scheme 4). ${ }^{11}$

We attempted to prepare the $3 \mathrm{a}, 4,6 \mathrm{a}, 7,8,9$-hexahydroazuleno-[4,5- $b]$ furans 28-31 directly from the acyclic precursors in a one-pot fashion, as outlined in Scheme 3 (conversion of 9 into 12). In a preliminary study, the diene-containing cyclisation precursor 35 was prepared from the known $\alpha, \beta$-unsaturated aldehyde $32^{13}$ as shown in Scheme 7 . The diene 33 was prepared by alkylidenation of the aldehyde 32 with isopropylidene triphenylphosphorane. Alkyne desilylation followed by formylation then afforded the propargylic aldehyde 34. Knoevenagel reaction of the aldehyde $\mathbf{3 4}$ with acetylacetone produced the ynenedione $\mathbf{3 5}$ and subsequent acid-mediated cyclisation in dichloromethane at $40{ }^{\circ} \mathrm{C}$ afforded the 1-furanyl2-vinylcyclopropane 36 in 59\% yield. This Cope rearrangement

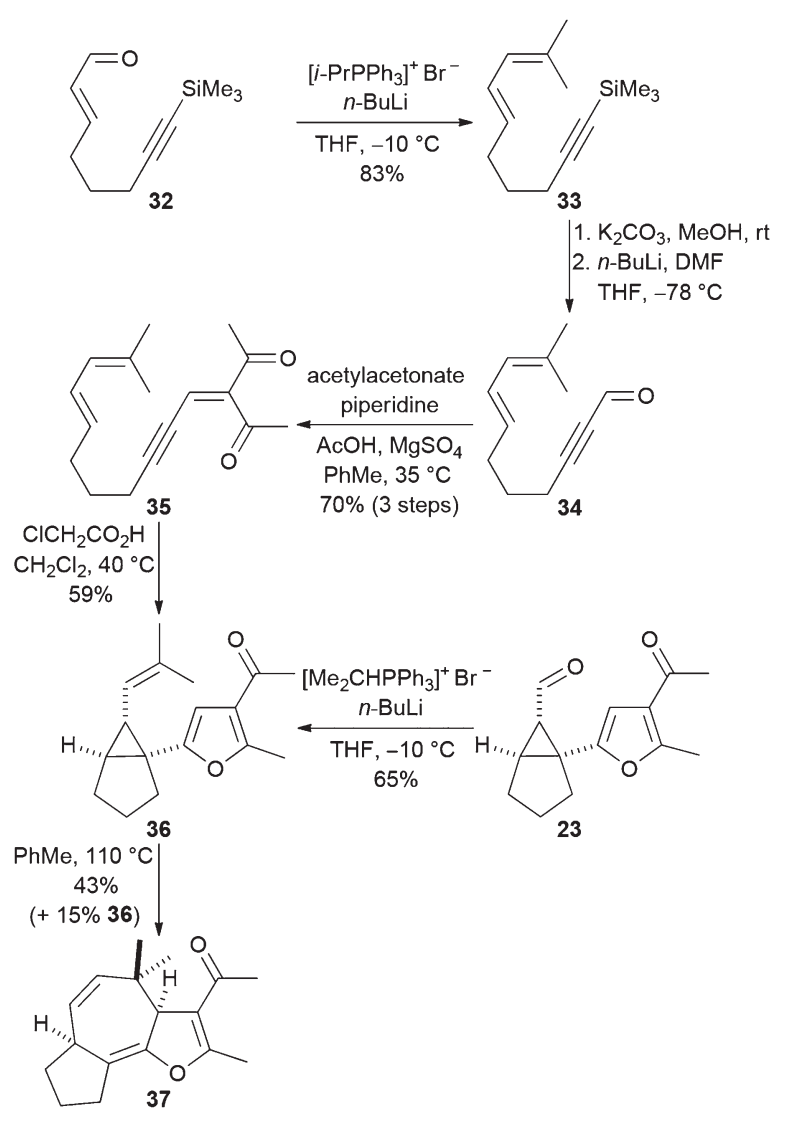

Scheme 7 Direct acid-catalysed synthesis of the rearrangement precursor $\mathbf{2 7}$ from an acyclic diene-tethered ynenone. precursor was also obtained by alkylidenation of the aldehyde 23 that we had prepared previously (Scheme 5).

The trisubstituted alkene $\mathbf{3 6}$ did not undergo Cope rearrangement when heated at $40{ }^{\circ} \mathrm{C}$ as a solution in toluene and so the reaction temperature was increased to $110{ }^{\circ} \mathrm{C}$. After a reaction time of three days, $15 \%$ of the starting material was recovered and the fused tricyclic product 37 was isolated in $43 \%$ yield (51\% yield when recovered starting material is considered). Reducing the reaction time to 24 hours resulted in a lower conversion $(32 \%)$ but a higher yield $(68 \%)$ based on the amount of recovered starting material, a finding which suggests that either the substrate or product decomposes when heated at $110{ }^{\circ} \mathrm{C}$ for several days. Unfortunately, it was not possible to perform Knoevenagel condensation, acid-catalysed cyclisation and Cope rearrangement in a one-pot fashion to give the tricyclic ketone $\mathbf{3 7}$ directly from the aldehyde $\mathbf{3 4}$ because of the relatively high reaction temperature $\left(110^{\circ} \mathrm{C}\right)$ required to accomplish Cope rearrangement of the furan 36 .

Attempts to perform acid-catalysed cyclisation reactions with other diene-containing ynenediones, analogous to the substrate 35, were hampered by the fact that the propargylic aldehydes bearing tethered dienes, required for the preceding Knoevenagel condensation reaction, underwent competitive intramolecular Diels-Alder cycloaddition and complex mixtures of products were obtained instead of the required ynenediones.

\section{Computational study of the Cope rearrangement of the isomers of the vinylcyclopropane-substituted furan 25}

DFT calculations were performed to explain the outcome of the reactions of substrates 25-27 and, specifically, to quantify the effects of the configuration of the 1-propenyl double bond of the substrate $(\boldsymbol{E}-\mathbf{2 5}$ vs. $\boldsymbol{Z}$-25) on the Cope rearrangement reaction to give the product $\mathbf{2 9}$ (see Scheme 6). The calculated energetic and structural parameters for reactants, transition states, and products of the Cope rearrangement are collated in Table 3 . The rearrangement reaction proceeds as expected for a $[3,3]$ sigmatropic process and is largely unaffected by the configuration of the alkene. The distinct double bonds (1-2, $5-6)$ and single bonds (2-3, 4-5) of the reactant equalise in the transition state and localise again into distinct single and double bonds, respectively, in the product. Concomitant cleavage of the cyclopropane bond 3-4 and formation of the new bond between $\mathrm{C}^{1}$ and $\mathrm{C}^{6}$, creates the cycloheptadiene.

The configuration of the alkene has a minor effect on the relative stability of the reactants $\boldsymbol{E} / \boldsymbol{Z}-\mathbf{2 5}$, disfavouring the $Z$ isomer both enthalpically and entropically by $5 \mathrm{~kJ} \mathrm{~mol}^{-1}$ each. In $Z$-25, the 1-propenyl arm of the cyclopropane is rotated outwards about the single bond $2-3$ so that unfavourable steric interactions of the terminal methyl group with the rest of the molecule are avoided, which results in the long 6-1 distance (Fig. 2). However, in the transition state, as the bond 2-3 acquires increasing double-bond character and the propenyl arm approaches the furan, the configuration of TS- $Z$ results in steric clashes of the methyl group with the hydrogens $\mathrm{H}_{\mathrm{a}}$ and $\mathrm{H}_{\mathrm{b}}$ (see Scheme 6 and Fig. 2). In contrast, TS-E is sterically less 
Table 3 Relative potential energies $(\Delta E)$, entropies (expressed as energies $-T \Delta S$ ), Gibbs free energies $(\Delta G$ ), and bond lengths between the six carbons involved in the [3,3]-sigmatropic rearrangement reaction (atom numbering defined in Scheme 6). All values have been calculated with M062X/def2-TZVP at reaction conditions $(T=313.15 \mathrm{~K}, p=100 \mathrm{kPa})$

\begin{tabular}{|c|c|c|c|c|c|c|c|c|c|}
\hline & $\begin{array}{l}\Delta E \\
\left(\mathrm{~kJ} \mathrm{~mol}^{-1}\right)\end{array}$ & $\begin{array}{l}-T \Delta S \\
\left(\mathrm{~kJ} \mathrm{~mol}^{-1}\right)\end{array}$ & $\begin{array}{l}\Delta G \\
\left(\mathrm{~kJ} \mathrm{~mol}{ }^{-1}\right)\end{array}$ & \multicolumn{6}{|l|}{$d / \AA$} \\
\hline$E-25$ & 0 & 0 & 0 & 1.33 & 1.48 & 1.53 & 1.46 & 1.35 & 3.55 \\
\hline TS-E & 108 & 20 & 124 & 1.39 & 1.38 & 2.02 & 1.37 & 1.41 & 2.18 \\
\hline 29 & -23 & 19 & -1 & 1.51 & 1.33 & 2.55 & 1.32 & 1.50 & 1.54 \\
\hline$Z-25$ & 5 & 5 & 10 & 1.33 & 1.49 & 1.51 & 1.47 & 1.35 & 4.49 \\
\hline TS-Z & 126 & 20 & 142 & 1.39 & 1.39 & 1.99 & 1.37 & 1.40 & 2.23 \\
\hline
\end{tabular}

$E-25$

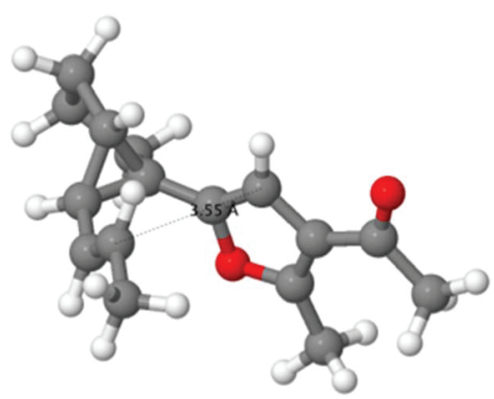

TS-E

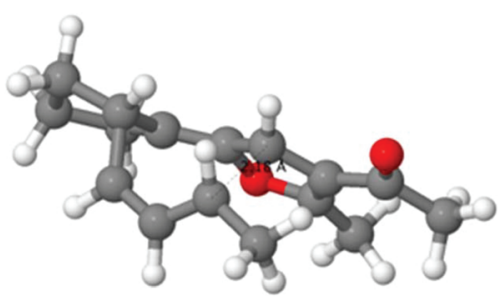

$Z-25$

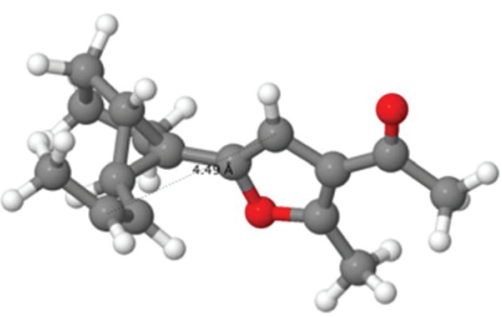

TS-Z

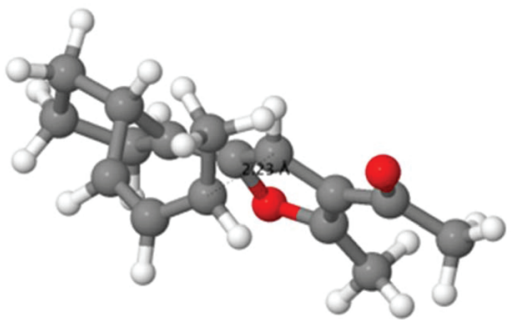

Fig. 2 Optimised structures of the reactants and transition states of the Cope rearrangement reaction.

encumbered, which is reflected in a lower enthalpic barrier for rearrangement of $\boldsymbol{E}-25\left(\Delta^{\ddagger} E\right.$ of $108 v s .121 \mathrm{~kJ} \mathrm{~mol}^{-1}$; barriers calculated relative to the energy of the respective starting com- pound). The entropic barrier is much smaller and similar for the two isomers ( $-T \Delta^{\ddagger} S$ of $20 v s .15 \mathrm{~kJ} \mathrm{~mol}^{-1}$ ). The more facile approach of $\mathrm{C}^{1}$ and $\mathrm{C}^{6}$ in TS-E is also reflected in a somewhat later transition state: the incipient $\mathrm{C}^{1}-\mathrm{C}^{6}$ bond is $0.05 \AA$ shorter in TS- $\boldsymbol{E}$ than in TS- $\boldsymbol{Z}$ and the breaking $\mathrm{C}^{3}-\mathrm{C}^{4}$ bond is $0.03 \AA$ A longer.

The Gibbs free energy barrier is $8 \mathrm{~kJ} \mathrm{~mol}^{-1}$ lower for TS-E than TS- $\boldsymbol{Z}$ and so rearrangement of the $\boldsymbol{E}-\mathbf{2 5}$ is kinetically favoured. In terms of reaction rates, this difference in barrier corresponds to a 20 -fold faster rate (at $40^{\circ} \mathrm{C}$ ) for the rearrangement of the $\boldsymbol{E}-\mathbf{2 5}$ relative to $\boldsymbol{Z}-\mathbf{2 5}$. The barrier is largely enthalpic and the entropic contribution is similar in both cases, so increasing the reaction temperature will not affect the kinetic selectivity significantly.

The tricyclic product 29 , resulting from the rearrangement of $\boldsymbol{E}-\mathbf{2 5}$, is also favoured on thermodynamic grounds. The formation of this compound is thermoneutral at $40{ }^{\circ} \mathrm{C}$, whereas the formation of $\boldsymbol{e p i - 2 9}$ from $\boldsymbol{Z}$-25 is endergonic by $10 \mathrm{~kJ} \mathrm{~mol}^{-1}$. The difference stems exclusively from the enthalpic part of the reaction free energy, which is exothermic. Because the product is conformationally rigid, the entropic penalty incurred during formation of the transition state remains 'locked into' the product. The entropic part of the reaction free energy is therefore unfavourable, of similar (or even larger) magnitude than the enthalpic part, and similar for the two isomers. A higher reaction temperature will thus shift the equilibrium further to the left, equally so for both isomers.

The near-zero, or even positive, reaction free energy means that when the temperature is sufficiently high for the forward reaction to proceed at a significant rate, so will the backward reaction; that is, reactant and product are in equilibrium. At $40{ }^{\circ} \mathrm{C}$, the reaction free energies of -1 and $+10 \mathrm{~kJ} \mathrm{~mol}^{-1}$ for 29 and $\boldsymbol{e p i - 2 9 ,}$ respectively, correspond to equilibrium constants of 2.6 and 0.02 .

\section{Conclusions}

In summary, a new route for the stereoselective construction of hexahydroazuleno[4,5- $b]$ furans from simple acyclic precursors has been developed that involves an acid-catalysed cyclisation reaction to give 1-furanyl-2-vinylcyclopropanes and their subsequent Cope rearrangement. We have shown that 

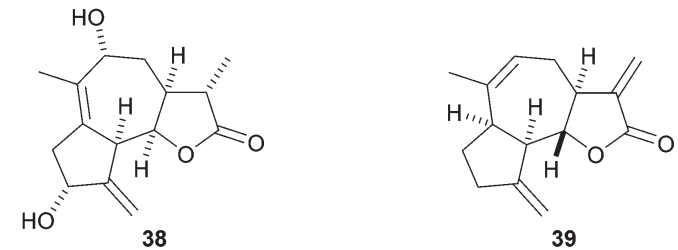

Fig. 3 Potential guaianolide natural product targets 38 and eremanthine (39).

$E$-configured substrates undergo smooth Cope rearrangement at $40{ }^{\circ} \mathrm{C}$ but the corresponding $Z$-isomers do not rearrange at this temperature. A cascade procedure for the direct formation of the tricyclic products from acyclic ynenone precursors was investigated, but in most cases intermediates underwent intramolecular Diels-Alder cycloaddition prior to, or during, the Knoevenagel condensation reaction used to prepare the precursors required for the furan-forming reaction. The Cope rearrangement product $\mathbf{2 8}$ maps on the core structure found in sesquiterpene natural products of the guaianolide family, such as the lactones 38 and 39 (Fig. 3). ${ }^{16,17}$ Studies are in progress to apply this reaction to the synthesis of these and structurally related guaianolides.

\section{Experimental section}

Air or moisture-sensitive reactions were performed under an atmosphere of argon in flame-dried glassware.

When required, tetrahydrofuran, toluene, dichloromethane and diethyl ether were dried using a Pure-Solv ${ }^{\mathrm{TM}}$ solvent purification system. Other dry organic solvents and reagents were purchased from commercial supplies and used without further purification unless otherwise specified.

Reactions were monitored by thin-layer chromatography (TLC) on Merck silica gel 60 plates. The TLC plates were visualised under UV light and stained with acidic ethanolic anisaldehyde solution or potassium permanganate solution.

Column chromatography was performed under forced flow with silica gel (Fluorochem LC60A, 35-70 micron or Merck Geduran Si 60, 40-63 micron). Petroleum ether used for column chromatography was the $40-60^{\circ} \mathrm{C}$ fraction.

Melting points were recorded using an Electrothermal IA 9100 instrument.

IR spectra were recorded on a Shimadzu FT IR-8400S ATR instrument. The IR spectrum of each compound was acquired directly on a thin film (liquid) or powder (solid) at room temperature. ${ }^{1} \mathrm{H}$ NMR and ${ }^{13} \mathrm{C}$ NMR spectra were recorded using a Bruker Avance III $400 \mathrm{MHz}$ or Bruker Avance III UltraShield $500 \mathrm{MHz}$ spectrometer at ambient temperature. ${ }^{13} \mathrm{C} \mathrm{NMR}$ spectra were recorded at $101 \mathrm{MHz}$ or $126 \mathrm{MHz}$.

High resolution mass spectrometry (HRMS) was performed by the analytical service of the University of Glasgow with an Jeol MStation JMS-700 instrument using positive chemical ionization (CI using isobutene) or a positive ion impact (EI) techniques, or on a Bruker micro TOFq High Resolution instrument using positive ion electrospray (ESI) techniques.

\section{(E)-8-(Trimethylsilyl)-2-octen-7-yn-1-ol (18) ${ }^{13}$}

To a stirred solution of the ethyl (E)-8-(trimethylsilyl)-2-octen7-ynoate $(10.03 \mathrm{~g}, 42.07 \mathrm{mmol})$ in dichloromethane $(200 \mathrm{~mL})$ was added diisobutylaluminium hydride $(93 \mathrm{~mL}, 1.0 \mathrm{M}$ solution in hexane, $93 \mathrm{mmol})$ dropwise at $-78{ }^{\circ} \mathrm{C}$. The reaction was stirred at $-78{ }^{\circ} \mathrm{C}$ for $2 \mathrm{~h}$ and was then quenched by addition of methanol (50 mL) and of a saturated aqueous solution of Rochelle's salt $(200 \mathrm{~mL})$. The mixture was stirred for $3 \mathrm{~h}$ at room temperature and the phases were then separated. The aqueous phase was extracted with $\mathrm{Et}_{2} \mathrm{O}(2 \times 150 \mathrm{~mL})$ and the combined organic extracts were dried over $\mathrm{MgSO}_{4}$, filtered and concentrated under reduced pressure to give alcohol 18 $(8.24 \mathrm{~g})$, which was used for the next step without further purification.

\section{(E)-1-(t-Butyldimethylsilyloxy)-8-(trimethylsilyl)-2-octen-7-yne}

To a stirred solution of alcohol 18 (8.24 g, $42.0 \mathrm{mmol})$ in dichloromethane $(130 \mathrm{~mL})$ was added $t$-butyldimethylsilyl chloride $(7.0 \mathrm{~g}, 46 \mathrm{mmol})$, imidazole $(4.6 \mathrm{~g}, 68 \mathrm{mmol})$ and DMAP (50 $\mathrm{mg}, 0.41 \mathrm{mmol}$ ). The solution was stirred for one day at room temperature and the reaction was monitored by TLC. Further $t$-butyldimethylsilyl chloride ( $3 \mathrm{~g}, 0.02 \mathrm{~mol})$, imidazole ( $2 \mathrm{~g}, 0.03 \mathrm{~mol}$ ) and DMAP (10 $\mathrm{mg}, 0.082 \mathrm{mmol}$ ) were added and the solution was stirred for a further day. The reaction was quenched by addition of water $(100 \mathrm{~mL})$ and the phases were separated. The aqueous phase was extracted with dichloromethane $(3 \times 100 \mathrm{~mL})$ and the combined organic extracts were dried over $\mathrm{MgSO}_{4}$, filtered and concentrated under reduced pressure. The crude product was purified by flash column chromatography on silica gel (petroleum ether-Et ${ }_{2} \mathrm{O}, 99: 1$ ) to afford the title compound (13.0 g, 99\% over 2 steps).

\section{(E)-1-(t-Butyldimethylsilyloxy)-2-octen-7-yne}

To a stirred solution of (E)-1-( $t$-butyldimethylsilyl-oxy)-8-(trimethylsilyl)-2-octen-7-yne $(2.03 \mathrm{~g}, 6.54 \mathrm{mmol})$ in $\mathrm{MeOH}$ $(65 \mathrm{~mL})$ at $\mathrm{rt}$ was added $\mathrm{K}_{2} \mathrm{CO}_{3}(0.99 \mathrm{~g}, 7.2 \mathrm{mmol})$ in one portion. The mixture was stirred for $12 \mathrm{~h}$ and then the reaction was quenched by addition of water $(70 \mathrm{~mL})$. The mixture was diluted with $\mathrm{Et}_{2} \mathrm{O}(30 \mathrm{~mL})$ and the phases were separated. The aqueous phase was extracted with $\mathrm{Et}_{2} \mathrm{O}(3 \times 30 \mathrm{~mL})$ and the combined organic extracts were dried over $\mathrm{MgSO}_{4}$, filtered and concentrated under reduced pressure. The residue was purified by flash column chromatography on silica gel (petroleum ether-EtOAc, $300: 1)$ to afford (E)-1-(t-butyldimethylsilyloxy)-2octen-7-yne $(1.50 \mathrm{~g}, 96 \%)$ as a colourless oil. $R_{\mathrm{f}}=0.04$ (petroleum ether); ${ }^{1} \mathrm{H}$ NMR (400 $\left.\mathrm{MHz}, \mathrm{CDCl}_{3}\right) \delta 5.66-5.53(2 \mathrm{H}, \mathrm{m})$, 4.14-4.10 (2H, m), 2.20 (2H, td, $J=7.2,2.7 \mathrm{~Hz}), 2.17-2.12(2 \mathrm{H}$, $\mathrm{m}), 1.95(1 \mathrm{H}, \mathrm{t}, J=2.7 \mathrm{~Hz}), 1.61(2 \mathrm{H}, \mathrm{tt}, J=7.2,7.1 \mathrm{~Hz}), 0.90$ (9H, s), 0.07 (6H, s); ${ }^{13} \mathrm{C}$ NMR (101 MHz, $\left.\mathrm{CDCl}_{3}\right) \delta 130.3,130.0$, $84.4,68.5,64.0,31.2,28.1,26.1,18.6,18.0,-5.0 ; \nu_{\max }$ (film) 3325, 2955, 2930, 2897, 1472, 833, 816, 773, 731, 667, $629 \mathrm{~cm}^{-1}$; HRMS (ESI) calcd for $\mathrm{C}_{14} \mathrm{H}_{26} \mathrm{NaO}_{3} \mathrm{Si}[\mathrm{M}+\mathrm{Na}]^{+}$ 261.1645, found 261.1640 . 
3-[(E)-9-(t-Butyldimethylsilyloxy)-7-nonen-2-yn-1-ylidene]pentane-2,4-dione (20)

To a stirred solution of ( $E$ )-1-( $t$-butyl-dimethylsilyloxy)-2-octen7 -yne $(2.30 \mathrm{~g}, 9.64 \mathrm{mmol})$ in THF $(96 \mathrm{~mL})$ at $-78^{\circ} \mathrm{C}$ was added $n$-BuLi ( $6.6 \mathrm{~mL}$ of a $2.2 \mathrm{M}$ solution in hexanes, $15 \mathrm{mmol}$ ) over a period of $10 \mathrm{~min}$. The mixture was stirred at $-78{ }^{\circ} \mathrm{C}$ for $15 \mathrm{~min}$ and then anhydrous DMF $(1.5 \mathrm{~mL}, 19 \mathrm{mmol})$ was added. The mixture was stirred at $-78{ }^{\circ} \mathrm{C}$ for a further $30 \mathrm{~min}$ and then the reaction was quenched by addition of $10 \%$ aqueous $\mathrm{KH}_{2} \mathrm{PO}_{4}(100 \mathrm{~mL})$. The mixture was diluted with EtOAc $(50 \mathrm{~mL})$, stirred for $10 \mathrm{~min}$ and the phases were separated. The aqueous phase was extracted with EtOAc $(3 \times 50 \mathrm{~mL})$ and the combined organic extracts were washed with brine $\left(80 \mathrm{~mL}\right.$ ), dried over $\mathrm{MgSO}_{4}$, filtered and concentrated under reduced pressure to afford crude propargylic aldehyde 19 as a yellow oil. The aldehyde was used directly in the next step without further purification.

To a stirred solution of crude propargylic aldehyde 19 and acetylacetone $(0.99 \mathrm{~mL}, 9.6 \mathrm{mmol})$ in toluene $(10 \mathrm{~mL})$ at $\mathrm{rt}$ were added $\mathrm{MgSO}_{4}(0.23 \mathrm{~g}, 1.9 \mathrm{mmol})$ and ethylenediamine- $N$, $N^{\prime}$-diacetic acid $(0.17 \mathrm{~g}, 0.96 \mathrm{mmol})$. The mixture was stirred at $35{ }^{\circ} \mathrm{C}$ for $1 \mathrm{~h}$ and then the reaction was quenched by addition of saturated aqueous $\mathrm{NH}_{4} \mathrm{Cl}(30 \mathrm{~mL})$. The mixture was diluted with $\mathrm{Et}_{2} \mathrm{O}(20 \mathrm{~mL})$ and the phases were separated. The aqueous phase was extracted with $\mathrm{Et}_{2} \mathrm{O}(2 \times 10 \mathrm{~mL})$ and the combined organic extracts were washed with brine $(20 \mathrm{~mL})$, dried over $\mathrm{MgSO}_{4}$, filtered and concentrated under reduced pressure. The residue was purified by flash column chromatography on silica gel (petroleum ether-EtOAc, 10:1) to afford ynenedione 20 ( $2.33 \mathrm{~g}, 69 \%$ over 2 steps) as a pale yellow oil. $R_{\mathrm{f}}=0.09$ (petroleum ether-EtOAc, $\left.10: 1\right) ;{ }^{1} \mathrm{H}$ NMR $(500 \mathrm{MHz}$, $\left.\mathrm{CDCl}_{3}\right) \delta 6.68(1 \mathrm{H}, \mathrm{t}, J=2.5 \mathrm{~Hz}), 5.63-5.52(2 \mathrm{H}, \mathrm{m}), 4.12-4.10$ $(2 \mathrm{H}, \mathrm{m}), 2.45(3 \mathrm{H}, \mathrm{s}), 2.43(2 \mathrm{H}, \mathrm{td}, J=7.2,2.4 \mathrm{~Hz}), 2.30(3 \mathrm{H}, \mathrm{s})$, 2.15-2.09 (2H, m), $1.64(2 \mathrm{H}, \mathrm{tt}, J=7.2,7.1 \mathrm{~Hz}), 0.89(9 \mathrm{H}, \mathrm{s})$, $0.05(6 \mathrm{H}, \mathrm{s}) ;{ }^{13} \mathrm{C}$ NMR $\left(126 \mathrm{MHz}, \mathrm{CDCl}_{3}\right) \delta 201.4,195.9,149.7$, $130.7,129.4,123.3,110.1,77.2,63.9,31.3,31.1,27.7,27.3$, 26.1, 19.7, 18.6, -5.0, -5.0; $\nu_{\max }$ (film) 2930, 2833, 2208, 1718, 1692, 1667, 970, 835, $775 \mathrm{~cm}^{-1}$; HMRS (ESI) calcd for $\mathrm{C}_{20} \mathrm{H}_{32} \mathrm{NaO}_{3} \mathrm{Si}[\mathrm{M}+\mathrm{Na}]^{+}$371.2013, found 371.1997.

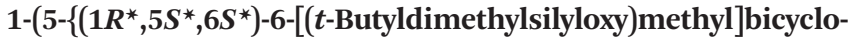

\section{[3.1.0]hex-1-yl\}-2-methyl-3-furanyl)ethanone (21)}

To a stirred solution of ynenedione $20(2.03 \mathrm{~g}, 5.82 \mathrm{mmol})$ in $\mathrm{CH}_{2} \mathrm{Cl}_{2}(23 \mathrm{~mL})$ at $\mathrm{rt}$ was added chloroacetic acid $(0.55 \mathrm{~g}$, $5.8 \mathrm{mmol}$ ) in one portion. The mixture was stirred at $40^{\circ} \mathrm{C}$ for $4 \mathrm{~d}$ and then concentrated under reduced pressure. The residue was purified by flash column chromatography on silica gel (petroleum ether-EtOAc, $10: 1)$ to afford furan 21 (1.77 g, $87 \%$ ) as a pale yellow oil. $R_{\mathrm{f}}=0.45$ (petroleum ether-EtOAc, $10: 1) ;{ }^{1} \mathrm{H}$ NMR $\left(500 \mathrm{MHz}, \mathrm{CDCl}_{3}\right) \delta 6.27(1 \mathrm{H}, \mathrm{s}), 3.60(1 \mathrm{H}, \mathrm{dd}$, $J=11.0,6.4 \mathrm{~Hz}), 3.44(1 \mathrm{H}, \mathrm{dd}, J=11.0,7.8 \mathrm{~Hz}), 2.53(3 \mathrm{H}, \mathrm{s})$, $2.36(3 \mathrm{H}, \mathrm{s}), 2.13(1 \mathrm{H}, \mathrm{dd}, J=12.5,8.0 \mathrm{~Hz}), 1.90-1.80(3 \mathrm{H}, \mathrm{m})$, $1.75-1.67(1 \mathrm{H}, \mathrm{m}), 1.53(1 \mathrm{H}, \mathrm{dd}, J=4.0,4.0 \mathrm{~Hz}), 1.38-1.29(2 \mathrm{H}$, $\mathrm{m}) ; 0.84(9 \mathrm{H}, \mathrm{s}),-0.03(3 \mathrm{H}, \mathrm{s}),-0.04(3 \mathrm{H}, \mathrm{s}) ;{ }^{13} \mathrm{C}$ NMR $\left(126 \mathrm{MHz}, \mathrm{CDCl}_{3}\right) \delta 194.5,157.0,154.6,122.0,106.4,62.8$,
33.0, 30.7, 29.3, 29.0, 27.8, 27.5, 26.0, 22.0, 18.4, 14.6, -5.1, $-5.2 ; \nu_{\max }$ (film) 2955, 2928, 2863, 1678, 1570, 947, 835, $775 \mathrm{~cm}^{-1}$; HRMS (EI) calcd for $\mathrm{C}_{20} \mathrm{H}_{32} \mathrm{O}_{3} \mathrm{Si}[\mathrm{M}]^{+}$348.2121, found 348.2125; anal. calcd for $\mathrm{C}_{20} \mathrm{H}_{32} \mathrm{O}_{3} \mathrm{Si}$ : C, 68.92\%; $\mathrm{H}$, 9.25\%. Found: C, $68.71 \%$; H, 9.11\%.

1-(5- $\left\{\left(1 R^{*}, 5 S^{*}, 6 S^{*}\right)-6-(H y d r o x y m e t h y l) b i c y c l o[3.1 .0]\right.$ hex-1-yl $\}-2-$ methyl-3-furanyl)ethanone (22)

To a stirred solution of protected alcohol 21 (247 mg, $0.709 \mathrm{mmol})$ in $\mathrm{MeOH} / \mathrm{CH}_{2} \mathrm{Cl}_{2}(\mathrm{v} / \mathrm{v} 5: 2,7 \mathrm{~mL})$ at rt was added 10-camphorsulfonic acid (32 $\mathrm{mg}, 0.14 \mathrm{mmol})$ in one portion. The mixture was stirred for $1 \mathrm{~h}$ and then the reaction was quenched by addition of water $(20 \mathrm{~mL})$ and saturated aqueous $\mathrm{NaHCO}_{3}(5 \mathrm{~mL})$. The mixture was diluted with $\mathrm{Et}_{2} \mathrm{O}(10 \mathrm{~mL})$ and the phases were separated. The aqueous phase was extracted with $\mathrm{Et}_{2} \mathrm{O}(3 \times 5 \mathrm{~mL})$ and the combined organic extracts were washed with brine $(2 \times 5 \mathrm{~mL})$, dried over $\mathrm{MgSO}_{4}$, filtered and concentrated under reduced pressure. The residue was purified by flash column chromatography on silica gel (petroleum ether-EtOAc, 2:1) to afford alcohol $22(151 \mathrm{mg}$, $89 \%$ ) as a colourless oil. $R_{\mathrm{f}}=0.08$ (petroleum ether-EtOAc, $2: 1) ;{ }^{1} \mathrm{H}$ NMR $\left(500 \mathrm{MHz}, \mathrm{CDCl}_{3}\right) \delta 6.30(1 \mathrm{H}, \mathrm{s}), 3.69(1 \mathrm{H}, \mathrm{ddd}$, $J=11.5,6.5,6.5 \mathrm{~Hz}), 3.36(1 \mathrm{H}, \mathrm{ddd}, J=11.5,8.8,3.3 \mathrm{~Hz}), 2.55$ $(3 \mathrm{H}, \mathrm{s}), 2.37(3 \mathrm{H}, \mathrm{s}), 2.16(1 \mathrm{H}, \mathrm{dd}, J=12.4,8.0 \mathrm{~Hz}), 1.90-1.81$ $(3 \mathrm{H}, \mathrm{m}), 1.77-1.70(1 \mathrm{H}, \mathrm{m}), 1.59(1 \mathrm{H}, \mathrm{dd}, J=4.0,4.0 \mathrm{~Hz})$, 1.44-1.31 (3H, m); ${ }^{13} \mathrm{C}$ NMR $\left(126 \mathrm{MHz}, \mathrm{CDCl}_{3}\right) \delta 194.3,157.2$, 154.5, 122.2, 106.9, 62.8, 33.1, 30.6, 29.3, 29.2, 27.8, 27.4, 22.1, 14.6; $\nu_{\max }$ (film) 3410 (br), 2953, 2928, 2862, 1663, 1566, 947, 802, 675, $630 \mathrm{~cm}^{-1}$; HRMS (EI) calcd for $\mathrm{C}_{14} \mathrm{H}_{18} \mathrm{O}_{3}[\mathrm{M}]^{+}$ 234.1256, found 234.1257.

\section{$\left(1 R^{*}, 5 S^{*}, 6 S^{*}\right)$-1-(4-Acetyl-5-methyl-2-furanyl)bicyclo[3.1.0]-} hexane-6-carboxaldehyde (23)

To a stirred solution of alcohol $22(0.15 \mathrm{~g}, 0.64 \mathrm{mmol})$ in $\mathrm{CH}_{2} \mathrm{Cl}_{2}(7 \mathrm{~mL})$ at $0{ }^{\circ} \mathrm{C}$ was added Dess-Martin periodinane $(0.45 \mathrm{~g}, 1.1 \mathrm{mmol})$ in small portions. The mixture was stirred at $\mathrm{rt}$ for $16 \mathrm{~h}$ and then the reaction was quenched by sequential addition of saturated aqueous $\mathrm{Na}_{2} \mathrm{~S}_{2} \mathrm{O}_{3}(10 \mathrm{~mL})$ and saturated aqueous $\mathrm{NaHCO}_{3}(10 \mathrm{~mL})$. The mixture was diluted with $\mathrm{Et}_{2} \mathrm{O}(10 \mathrm{~mL})$, stirred until two clear layers were obtained ( $c a$. $30 \mathrm{~min})$ and the phases were separated. The aqueous phase was extracted with $\mathrm{Et}_{2} \mathrm{O}(3 \times 10 \mathrm{~mL})$ and the combined organic extracts were dried over $\mathrm{MgSO}_{4}$, filtered and concentrated under reduced pressure. The residue was purified by flash column chromatography on silica gel (petroleum ether-EtOAc, $10: 3)$ to afford aldehyde $23(0.14 \mathrm{~g}, 94 \%)$ as a pale yellow oil. $R_{\mathrm{f}}=0.16$ (petroleum ether-EtOAc, $\left.10: 3\right) ;{ }^{1} \mathrm{H}$ NMR $(400 \mathrm{MHz}$, $\left.\mathrm{CDCl}_{3}\right) \delta 9.03(1 \mathrm{H}, \mathrm{d}, J=6.5 \mathrm{~Hz}), 6.37(1 \mathrm{H}, \mathrm{s}), 2.55(1 \mathrm{H}, \mathrm{dd}, J=$ $4.0,3.9 \mathrm{~Hz}), 2.53(3 \mathrm{H}, \mathrm{s}), 2.36(3 \mathrm{H}, \mathrm{s}), 2.26(1 \mathrm{H}, \mathrm{dd}, J=13.0,8.4$ $\mathrm{Hz}), 2.10-1.97(3 \mathrm{H}, \mathrm{m}), 2.05(1 \mathrm{H}, \mathrm{dd}, J=6.5,4.0 \mathrm{~Hz}), 1.81(1 \mathrm{H}$, ddd, $J=13.7,8.4,8.4 \mathrm{~Hz}$ ), $1.33(1 \mathrm{H}$, ddddd, $J=13.7,11.3,11.3$, 8.4, 8.4 Hz); ${ }^{13} \mathrm{C}$ NMR $\left(101 \mathrm{MHz}, \mathrm{CDCl}_{3}\right) \delta 199.7,194.0,157.6$, 151.3, 122.2, 107.9, 37.5, 36.6, 33.5, 32.4, 29.3, 27.3, 20.9, 14.6; $\nu_{\max }$ (film) 2959, 2942, 2867, 2743, 1701, 1674, 1568, 949, 810, $631 \mathrm{~cm}^{-1}$; HRMS (ESI) calcd for $\mathrm{C}_{14} \mathrm{H}_{16} \mathrm{NaO}_{3}[\mathrm{M}+\mathrm{Na}]^{+}$ 255.0992, found 255.0991. 
1-(5- $\left\{\left(1 R^{*}, 5 S^{*}, 6 S^{*}\right)-6-\right.$ Ethenylbicyclo[3.1.0]hex-1-yl $\}-2-m e t h y l-3-$ furanyl)ethanone (24)

To a stirred solution of methyltriphenylphosphonium bromide $(0.21 \mathrm{~g}, 0.59 \mathrm{mmol})$ in THF $(8 \mathrm{~mL})$ at $-10^{\circ} \mathrm{C}$ was added $n$-BuLi $(0.16 \mathrm{~mL}$ of a $2.3 \mathrm{M}$ solution in hexanes, $0.37 \mathrm{mmol})$. The mixture was stirred at $-10{ }^{\circ} \mathrm{C}$ for $1 \mathrm{~h}$ and then added to a stirred solution of aldehyde $23(71 \mathrm{mg}, 0.31 \mathrm{mmol})$ in THF $(10 \mathrm{~mL})$ at $-10^{\circ} \mathrm{C}$. The mixture was stirred at $\mathrm{rt}$ for $2 \mathrm{~h}$ and then the reaction was quenched by pouring the solution into a mixture of $\mathrm{pH} 7$ buffer $(50 \mathrm{~mL})$ and $\mathrm{Et}_{2} \mathrm{O}(20 \mathrm{~mL})$. The mixture was stirred for $10 \mathrm{~min}$ and the phases were separated. The aqueous phase was extracted with $\mathrm{Et}_{2} \mathrm{O}(3 \times 20 \mathrm{~mL})$ and the combined organic extracts were dried over $\mathrm{MgSO}_{4}$, filtered and concentrated under reduced pressure. The residue was purified by flash column chromatography on aluminium oxide (activated, basic Brockmann I, petroleum ether-EtOAc, $10: 1$ ) to afford vinylcyclopropane $24(57 \mathrm{mg}, 81 \%)$ as a colourless oil. $R_{\mathrm{f}}=0.13$ (petroleum ether-EtOAc, $\left.10: 1\right) ;{ }^{1} \mathrm{H}$ NMR $(400 \mathrm{MHz}$, $\left.\mathrm{CDCl}_{3}\right) \delta 6.25(1 \mathrm{H}, \mathrm{s}), 5.39(1 \mathrm{H}, \mathrm{ddd}, J=17.1,10.2,9.3 \mathrm{~Hz})$, $5.08(1 \mathrm{H}, \mathrm{dd}, J=17.1,1.8 \mathrm{~Hz}), 4.88(1 \mathrm{H}, \mathrm{dd}, J=10.2,1.8 \mathrm{~Hz})$, $2.54(3 \mathrm{H}, \mathrm{s}), 2.37(3 \mathrm{H}, \mathrm{s}), 2.16(1 \mathrm{H}, \mathrm{dd}, J=12.6,8.4 \mathrm{~Hz})$, 1.96-1.87 (3H, m), 1.81-1.78 (1H, m), 1.77-1.71 (1H, m), 1.74 $(1 \mathrm{H}, \mathrm{dd}, J=4.0,9.1 \mathrm{~Hz}), 1.44-1.32(1 \mathrm{H}, \mathrm{m}) ;{ }^{13} \mathrm{C} \mathrm{NMR}$ $\left(126 \mathrm{MHz}, \mathrm{CDCl}_{3}\right) \delta 194.5,157.1,154.4,137.1,122.1,113.9$, 106.5, 33.4, 32.7, 32.4, 30.2, 29.3, 27.5, 21.7, 14.6; $\nu_{\max }$ (film) 2955, 2926, 2862, 1678, 1570, 949, 889, $633 \mathrm{~cm}^{-1}$; HMRS (ESI) calcd for $\mathrm{C}_{15} \mathrm{H}_{18} \mathrm{NaO}_{2}[\mathrm{M}+\mathrm{Na}]^{+}$253.1199, found 253.1187.

\section{1-(5- $\left\{\left(1 R^{*}, 5 S^{*}, 6 S^{*}\right)-6-(1-P r o p e n y l) b i c y c l o[3.1 .0] h e x-1-y l\right\}-2-$} methyl-3-furanyl)ethanone ( $E$-25 and $Z$-25)

Wittig reaction (method A). To a stirred solution of ethyltriphenylphosphonium bromide $(0.14 \mathrm{~g}, 0.38 \mathrm{mmol})$ in THF $(5 \mathrm{~mL})$ at $-10{ }^{\circ} \mathrm{C}$ was added $n$-BuLi $(0.13 \mathrm{~mL}$ of a $2.2 \mathrm{M}$ solution in hexanes, $0.29 \mathrm{mmol}$ ). The mixture was stirred at $-10^{\circ} \mathrm{C}$ for $1 \mathrm{~h}$ and then added to a stirred solution of aldehyde 23 (59 $\mathrm{mg}, 0.25 \mathrm{mmol})$ in THF $(9 \mathrm{~mL})$ at $-10{ }^{\circ} \mathrm{C}$. The mixture was stirred at rt for $2 \mathrm{~h}$ and then the reaction was quenched by pouring the solution into a mixture of $\mathrm{pH} 7$ buffer $(20 \mathrm{~mL})$ and $\mathrm{Et}_{2} \mathrm{O}(10 \mathrm{~mL})$. The mixture was stirred for $10 \mathrm{~min}$ and the phases were separated. The aqueous phase was extracted with $\mathrm{Et}_{2} \mathrm{O}(3 \times 5 \mathrm{~mL})$ and the combined organic extracts were dried over $\mathrm{MgSO}_{4}$, filtered and concentrated under reduced pressure. The residue was purified by flash column chromatography on aluminium oxide (activated, basic Brockmann I, petroleum ether-EtOAc, $10: 1$ ) to afford an inseparable mixture of $\boldsymbol{E}-25$ and Z-25 (49 mg, 79\%; $27: 73 E: Z$ ) as a colourless oil.

Julia-Kocienski olefination (method B). To a stirred solution of the aldehyde 23 (159 mg, $0.684 \mathrm{mmol}$ ) and 5-ethanesulfonyl-1-phenyl- $1 H$-tetrazole $(211 \mathrm{mg}, 0.886 \mathrm{mmol})$ in THF (11 $\mathrm{mL})$ was added KHMDS $(1.91 \mathrm{~mL}, 0.5 \mathrm{M}$ solution in toluene, $0.96 \mathrm{mmol}$ ) dropwise over a period of $1 \mathrm{~h}$ at $-78{ }^{\circ} \mathrm{C}$. The mixture was stirred at $-78{ }^{\circ} \mathrm{C}$ for $3 \mathrm{~h}$ and the reaction was then quenched by pouring the solution into a mixture of $\mathrm{pH} 7$ buffer $(40 \mathrm{~mL})$ and $\mathrm{Et}_{2} \mathrm{O}(10 \mathrm{~mL})$. The mixture was stirred for $10 \mathrm{~min}$ and the phases were separated. The aqueous phase was extracted with $\mathrm{Et}_{2} \mathrm{O}(3 \times 20 \mathrm{~mL})$ and the combined organic extracts were dried over $\mathrm{MgSO}_{4}$, filtered and concentrated under reduced pressure. The residue was purified by flash column chromatography on aluminium oxide (activated, basic Brockmann I, petroleum ether-EtOAc, $10: 1$ ) to afford an inseparable mixture of $\boldsymbol{E}-25$ and $\boldsymbol{Z}-25$ (85 $\mathrm{mg}, 51 \% ; 87: 13, E: Z$ ) as a colourless oil. $R_{\mathrm{f}}=0.16$ (petroleum ether-EtOAc, $10: 1$ ); ${ }^{1} \mathrm{H}$ NMR (400 MHz, C $\left.6 \mathrm{D}_{6}\right) \delta 6.18(1 \mathrm{H}, \mathrm{s}), 6.18(1 \mathrm{H}, \mathrm{s}), 5.50(1 \mathrm{H}, \mathrm{dq}$, $J=15.2,6.5 \mathrm{~Hz}), 5.44(1 \mathrm{H}, \mathrm{dqd}, J=10.8,6.8,1.0 \mathrm{~Hz}), 5.25-5.21$ (1H, m), 5.19 (1H, ddq, $J=10.8,9.5,1.7 \mathrm{~Hz}), 2.37(3 \mathrm{H}, \mathrm{s}), 2.37$ $(3 \mathrm{H}, \mathrm{s}), 2.11(1 \mathrm{H}, \mathrm{ddd}, J=12.5,8.2,0.6 \mathrm{~Hz}), 2.08(1 \mathrm{H}, \mathrm{dd}, J=$ 8.0, 4.5, $1.0 \mathrm{~Hz}), 1.94-1.84(4 \mathrm{H}, \mathrm{m}), 2.02(3 \mathrm{H}, \mathrm{s}), 2.02(3 \mathrm{H}, \mathrm{s})$, 1.73-1.67 (6H, m), 1.64 (3H, dd, $J=6.8,1.7 \mathrm{~Hz}), 1.54$ (3H, dd, $J=6.5,1.6 \mathrm{~Hz}), 1.51-1.43(1 \mathrm{H}, \mathrm{m}), 1.51-1.43(1 \mathrm{H}, \mathrm{m}), 1.22-1.07$ $(1 \mathrm{H}, \mathrm{m}), 1.22-1.07(1 \mathrm{H}, \mathrm{m}) ;{ }^{13} \mathrm{C} \mathrm{NMR}\left(126 \mathrm{MHz}, \mathrm{C}_{6} \mathrm{D}_{6}\right) \delta 192.6$, $192.6,156.7,156.6,154.7,154.6,129.8,129.2$, 125.0, 123.9, 122.6, 122.5, 106.9, 106.8, 33.6, 33.2, 33.1, 33.0, 33.0, 32.1, $29.5,28.9,27.8,27.7,24.7,22.1,22.0,18.2,14.3,14.3,13.5$; $\nu_{\max }($ film) 3023, 2955, 2933, 2862, 1676, 1569, 949, 730, $632 \mathrm{~cm}^{-1}$; HMRS (ESI) calcd for $\mathrm{C}_{16} \mathrm{H}_{20} \mathrm{NaO}_{2}[\mathrm{M}+\mathrm{Na}]^{+}$ 267.1356, found 267.1343.

1-(5- $\left\{\left(1 R^{*}, 5 S^{*}, 6 S^{*}\right)-6\right.$-(3-Methyl-1-buten-1-yl)bicyclo[3.1.0]hex-1yl\}-2-methyl-3-furanyl)-ethanone ( $E-26$ and $Z-26)$

Wittig reaction (method A). To a stirred solution of isobutyltriphenylphosphonium bromide (297 $\mathrm{mg}, 0.740 \mathrm{mmol}$ ) in THF $(10 \mathrm{~mL})$ at $-10^{\circ} \mathrm{C}$ was added $n$-BuLi $(0.24 \mathrm{~mL}$ of a $2.3 \mathrm{M}$ solution in hexanes, $0.55 \mathrm{mmol}$ ). The mixture was stirred at $-10^{\circ} \mathrm{C}$ for $1 \mathrm{~h}$ and then added to a stirred solution of aldehyde $\mathbf{2 3}$ (108 $\mathrm{mg}, 0.465 \mathrm{mmol})$ in THF $(16 \mathrm{~mL})$ at $-10{ }^{\circ} \mathrm{C}$. The mixture was stirred for $2 \mathrm{~h}$ at $-10{ }^{\circ} \mathrm{C}$ and then the reaction was quenched by pouring the solution into a mixture of $\mathrm{pH} 7$ buffer $(50 \mathrm{~mL})$ and $\mathrm{Et}_{2} \mathrm{O}(20 \mathrm{~mL})$. The mixture was stirred for $10 \mathrm{~min}$ and the phases were separated. The aqueous phase was extracted with $\mathrm{Et}_{2} \mathrm{O}(3 \times 20 \mathrm{~mL})$ and the combined organic extracts were dried over $\mathrm{MgSO}_{4}$, filtered and concentrated under reduced pressure. The residue was purified by flash column chromatography on aluminium oxide (activated, basic Brockmann I, petroleum ether-EtOAc, 96:4) to afford an inseparable mixture of $\boldsymbol{E}$-26 and $\boldsymbol{Z}$-26 (38 $\mathrm{mg}, 30 \%$; $12: 88 E: Z$ ) as a colourless oil.

Julia-Kocienski olefination (method B). To a stirred solution of the aldehyde 23 (98 mg, $0.42 \mathrm{mmol}$ ) and 5-(2-methylpropane-1-sulfonyl)-1-phenyl- $1 H$-tetrazole $(146 \quad \mathrm{mg}$, $0.548 \mathrm{mmol})$ in THF $(7 \mathrm{~mL})$ was added KHMDS $(1.18 \mathrm{~mL}, 0.5$ $\mathrm{M}$ solution in toluene, $0.59 \mathrm{mmol}$ ) dropwise at $-78{ }^{\circ} \mathrm{C}$ over a period of $1 \mathrm{~h}$. The mixture was stirred at $-78^{\circ} \mathrm{C}$ for $2.5 \mathrm{~h}$ and then at $\mathrm{rt}$ for $3 \mathrm{~h}$. The reaction was quenched by pouring the solution into a mixture of $\mathrm{pH} 7$ buffer $(30 \mathrm{~mL})$ and $\mathrm{Et}_{2} \mathrm{O}$ $(10 \mathrm{~mL})$. The mixture was stirred for $10 \mathrm{~min}$ and the phases were separated. The aqueous phase was extracted with $\mathrm{Et}_{2} \mathrm{O}$ $(3 \times 20 \mathrm{~mL})$ and the combined organic extracts were dried over $\mathrm{MgSO}_{4}$, filtered and concentrated under reduced pressure. The residue was purified by flash column chromatography on aluminium oxide (activated, basic Brockmann I, petroleum ether-EtOAc, $97: 3$ ) to afford an inseparable mixture of $\boldsymbol{E}-26$ 
and $Z$-26 (20 mg, 17\%; $87: 13, E: Z)$ as a colourless oil. $\boldsymbol{E}-26{ }^{1} \mathrm{H}$ NMR (400 MHz, $\left.\mathrm{C}_{6} \mathrm{D}_{6}\right) \delta 6.18(1 \mathrm{H}, \mathrm{s}), 5.49(1 \mathrm{H}, \mathrm{dd}, J=15.4,6.8$ $\mathrm{Hz}), 5.20$ (1H, ddd, $J=15.4,8.4,1.0 \mathrm{~Hz}$ ), 2.40 (3H, s), 2.22-2.11 (1H, m), 2.09-2.04 (1H, m), $2.04(3 \mathrm{H}, \mathrm{s}), 1.93-1.85(1 \mathrm{H}, \mathrm{m})$, 1.75-1.64 (4H, m), 1.52-1.43 (1H, m), 1.19-1.06 (1H, m), 0.92 $(3 \mathrm{H}, \mathrm{d}, J=6.7 \mathrm{~Hz}), 0.91(3 \mathrm{H}, \mathrm{d}, J=6.7 \mathrm{~Hz}) ; Z-26{ }^{1} \mathrm{H}$ NMR $\left(400 \mathrm{MHz}, \mathrm{C}_{6} \mathrm{D}_{6}\right) \delta 6.19(1 \mathrm{H}, \mathrm{s}), 5.27(1 \mathrm{H}, \mathrm{ddd}, J=10.8,9.2,1.0$ $\mathrm{Hz}), 5.07$ (1H, ddd, $J=10.7,9.3,1.1 \mathrm{~Hz}), 2.73(1 \mathrm{H}, \mathrm{dqqd}, J=$ 9.2, 6.7, 6.6, $1.0 \mathrm{~Hz}), 2.37(3 \mathrm{H}, \mathrm{s}), 2.11(1 \mathrm{H}, \mathrm{ddd}, J=12.6,8.3$, $0.9 \mathrm{~Hz}), 2.02(3 \mathrm{H}, \mathrm{s}), 1.93-1.85(2 \mathrm{H}, \mathrm{m}), 1.74-1.66(3 \mathrm{H}, \mathrm{m})$, 1.53-1.45 (1H, m), 1.22-1.11 (1H, m), $0.99(3 \mathrm{H}, \mathrm{d}, J=6.6 \mathrm{~Hz})$, $0.97(3 \mathrm{H}, \mathrm{d}, J=6.7 \mathrm{~Hz}) ; \boldsymbol{E}-26{ }^{13} \mathrm{C} \mathrm{NMR}\left(101 \mathrm{MHz}, \mathrm{C}_{6} \mathrm{D}_{6}\right)$ $\delta$ 192.6, 156.5, 154.6, 137.9, 125.8, 122.5, 107.0, 33.3, 32.9, 32.2 , 31.6, 29.1, 28.8, 27.7, 23.0, 22.9, 22.0, 14.3; Z-26 ${ }^{13} \mathrm{C}$ NMR $\left(101 \mathrm{MHz}, \mathrm{C}_{6} \mathrm{D}_{6}\right) \delta 192.6,156.7,154.5,137.8,126.1,122.5$, 106.9, 33.6, 33.2, 33.0, 28.8, 27.7, 27.5, 25.0, 23.4, 22.1, 14.3; $\nu_{\max }$ (film) 2955, 2930, 2864, 1676, 1570, 964, 945, 891, 802, 673, $633 \mathrm{~cm}^{-1}$; HMRS (ESI) calcd for $\mathrm{C}_{18} \mathrm{H}_{24} \mathrm{NaO}_{2}[\mathrm{M}+\mathrm{Na}]^{+}$ 295.1669, found 295.1661.

1-(5- $\left\{\left(1 R^{*}, 5 S^{*}, 6 S^{*}\right)\right.$-6-(2-Phenylethenyl)bicyclo[3.1.0]hex-1-yl $\}-2-$ methyl-3-furanyl)ethanone (E-27 and $Z$-27)

Wittig reaction (method A). To a stirred solution of benzyltriphenylphosphonium bromide $(0.14 \mathrm{~g}, 0.32 \mathrm{mmol})$ in THF $(4 \mathrm{~mL})$ at $-10^{\circ} \mathrm{C}$ was added $n$-BuLi $(0.12 \mathrm{~mL}$ of a $2.2 \mathrm{M}$ solution in hexanes, $0.26 \mathrm{mmol}$ ). The mixture was stirred at $-10{ }^{\circ} \mathrm{C}$ for $1 \mathrm{~h}$ and then added to a stirred solution of aldehyde 23 (50 mg, $0.22 \mathrm{mmol})$ in THF $(7 \mathrm{~mL})$ at $-10^{\circ} \mathrm{C}$. The mixture was stirred for $2 \mathrm{~h}$ at $-10^{\circ} \mathrm{C}$ and then the reaction was quenched by pouring the solution into a mixture of $\mathrm{pH} 7$ buffer $(50 \mathrm{~mL})$ and $\mathrm{Et}_{2} \mathrm{O}(20 \mathrm{~mL})$. The mixture was stirred for $10 \mathrm{~min}$ and the phases were separated. The aqueous phase was extracted with $\mathrm{Et}_{2} \mathrm{O}(3 \times 20 \mathrm{~mL})$ and the combined organic extracts were dried over $\mathrm{MgSO}_{4}$, filtered and concentrated under reduced pressure. The residue was purified by flash column chromatography on aluminium oxide (activated, basic Brockmann I, petroleum ether-EtOAc, $5: 1$ ) to afford an inseparable mixture of $\boldsymbol{E}-27$ and $Z$-27 (60 mg, 91\%; $47: 53, E: Z$ ) as a colourless oil.

Julia-Kocienski olefination (method B). To a stirred solution of the aldehyde 23 (50 mg, $0.22 \mathrm{mmol}$ ) and 5-phenylmethanesulfonyl-1-phenyl- $1 H$-tetrazole $(84 \mathrm{mg}, 0.28 \mathrm{mmol}$ ) in THF (4 mL) was added KHMDS ( $0.63 \mathrm{~mL}, 0.5 \mathrm{M}$ solution in toluene, $0.32 \mathrm{mmol}$ ) dropwise over a period of $1 \mathrm{~h}$ at $-78{ }^{\circ} \mathrm{C}$. The mixture was stirred at $-78{ }^{\circ} \mathrm{C}$ for $3 \mathrm{~h}$ and the reaction was then quenched by pouring the solution into a mixture of $\mathrm{pH} 7$ buffer $(15 \mathrm{~mL})$ and $\mathrm{Et}_{2} \mathrm{O}(10 \mathrm{~mL})$. The mixture was stirred for $10 \mathrm{~min}$ and the phases were separated. The aqueous phase was extracted with $\mathrm{Et}_{2} \mathrm{O}(3 \times 20 \mathrm{~mL})$ and the combined organic extracts were dried over $\mathrm{MgSO}_{4}$, filtered and concentrated under reduced pressure. The residue was purified by flash column chromatography on aluminium oxide (activated, basic Brockmann I, petroleum ether-EtOAc, $95: 5)$ to afford an inseparable mixture of $\boldsymbol{E}-27$ and $\boldsymbol{Z}-27$ (27 $\mathrm{mg}, 41 \%$; $70: 30, E: Z$ ) as a colourless oil. $R_{\mathrm{f}}=0.32$ (petroleum ether-EtOAc); ${ }^{1} \mathrm{H}$ NMR $\left(400 \mathrm{MHz}, \mathrm{C}_{6} \mathrm{D}_{6}\right) \delta 7.43(2 \mathrm{H}, \mathrm{d}, J=7.6 \mathrm{~Hz}), 7.23(2 \mathrm{H}, \mathrm{d}, J=7.9)$, $7.22(2 \mathrm{H}, \mathrm{dd}, J=7.6,7.9 \mathrm{~Hz}), 7.10-7.07(3 \mathrm{H}, \mathrm{m}), 6.98(1 \mathrm{H}, \mathrm{t}, J=$
$7.4 \mathrm{~Hz}), 6.45(1 \mathrm{H}, \mathrm{d}, J=15.8 \mathrm{~Hz}), 6.44(1 \mathrm{H}, \mathrm{d}, J=11.4 \mathrm{~Hz}), 6.23$ $(1 \mathrm{H}, \mathrm{s}), 6.22(1 \mathrm{H}, \mathrm{s}), 6.00(1 \mathrm{H}, \mathrm{dd}, J=15.8,9.2 \mathrm{~Hz}), 5.43(1 \mathrm{H}$, $\mathrm{dd}, J=11.4,9.3 \mathrm{~Hz}), 2.28(3 \mathrm{H}, \mathrm{s}), 2.36(3 \mathrm{H}, \mathrm{s}), 2.18(1 \mathrm{H}, \mathrm{dd}, J=$ 9.3, 4.2 Hz), 2.09 (1H, ddd, $J=12.6,8.2,5.6 \mathrm{~Hz}), 2.08$ (1H, ddd, $J=12.6,8.2,5.6 \mathrm{~Hz}), 2.03(3 \mathrm{H}, \mathrm{s}), 1.99$ (3H, s), 1.90 (1H, ddd, $J=12.6,11.5,8.6 \mathrm{~Hz}), 1.88(1 \mathrm{H}, \mathrm{ddd}, J=12.6,11.5,8.6 \mathrm{~Hz})$, 1.79-1.76 (2H, m), 1.75-1.71 (3H, m), 1.69-1.64 (2H, m), 1.52-1.46 (1H, m), 1.43-1.37 (1H, m), 1.21-1.12 (1H, m), 1.07-0.98 (1H, m); ${ }^{13} \mathrm{C}$ NMR (101 MHz, $\left.\mathrm{C}_{6} \mathrm{D}_{6}\right) \delta$ 192.6, 192.5, $156.8,156.7,154.3,154.2$, 138.2, 138.2, 130.9, 130.1, 129.6, 129.4 , 129.2, 128.9, 128.6, 127.1, 127.0, 126.1, 122.6, 122.6, 107.2, 107.0, 34.5, 34.3, 34.1, 33.2, 33.1, 32.6, 30.2, 28.9, 28.8, $27.8,27.6,26.7,21.9,21.9,14.3,14.2 ; \nu_{\max }$ (film) 2957, 2932, 2862, 1676, 1568, 945, 799, 767, 748, 694, 673, $633 \mathrm{~cm}^{-1}$; HMRS (ESI) calcd for $\mathrm{C}_{21} \mathrm{H}_{22} \mathrm{NaO}_{2}[\mathrm{M}+\mathrm{Na}]^{+} 329.1512$, found 329.1502.

$\left\{\left(3 \mathrm{a} S^{*}, 7 S^{*}\right)-3 \mathrm{a}, 4,6 \mathrm{a}, 7,8,9-H e x a h y d r o-2-m e t h y l a z u l e n o[4,5-b]-\right.$ furan-3-yl\}ethanone (28)

A solution of vinylcyclopropane $24(70 \mathrm{mg}, 0.30 \mathrm{mmol})$ in toluene $(6 \mathrm{~mL})$ was stirred at $40{ }^{\circ} \mathrm{C}$ for $16 \mathrm{~h}$. The mixture was concentrated under reduced pressure and the residue was purified by flash column chromatography on silica gel (petroleum ether-EtOAc, $10: 1)$ to afford cycloheptadiene 28 (44 mg, 63\%) as a pale yellow oil. $R_{\mathrm{f}}=0.49$ (petroleum ether-EtOAc, $10: 3$ ); ${ }^{1} \mathrm{H}$ NMR (400 MHz, $\left.\mathrm{C}_{6} \mathrm{D}_{6}\right) \delta$ 5.50-5.46 (2H, m), 4.18-4.14 $(1 \mathrm{H}$, $\mathrm{m}), 3.23-3.15(1 \mathrm{H}, \mathrm{m}), 2.77-2.68(1 \mathrm{H}, \mathrm{m}), 2.57-2.49(1 \mathrm{H}, \mathrm{m})$, 2.44-2.33 (1H, m), 2.08-1.97 (1H, m), 1.89 (3H, d, $J=1.4 \mathrm{~Hz})$, 1.85 (3H, s), 1.84-1.79 (1H, m), 1.60-1.53 (1H, m), 1.32-1.23 $(2 \mathrm{H}, \mathrm{m}) ;{ }^{13} \mathrm{C}$ NMR $\left(126 \mathrm{MHz}, \mathrm{C}_{6} \mathrm{D}_{6}\right) \delta 192.0,164.8,150.4,131.2$, 126.4, 118.6, 117.1, 44.2, 42.0, 36.4, 32.0, 29.4, 29.1, 25.0, 14.7; $\nu_{\text {max }}$ (film) 2953, 2935, 1744, 1668, 1618, 991, $949 \mathrm{~cm}^{-1}$; HMRS (ESI) calcd for $\mathrm{C}_{15} \mathrm{H}_{18} \mathrm{NaO}_{2}[\mathrm{M}+\mathrm{Na}]^{+}$253.1199, found 253.1187.

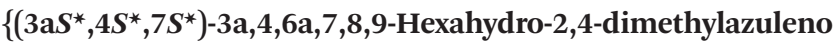 [4,5-b]furan-3-yl\}ethanone (29)}

An isomeric mixture of the vinylcyclopropanes 25 (35 mg, $0.14 \mathrm{mmol} ; 27: 73, E: Z)$ in toluene $(4 \mathrm{~mL})$ was stirred at $40{ }^{\circ} \mathrm{C}$ for $18 \mathrm{~h}$. The mixture was concentrated under reduced pressure and the residue was purified by flash column chromatography on silica gel (petroleum ether-EtOAc, 10:1) to afford cycloheptadiene $29(7.9 \mathrm{mg}, 23 \%)$ as a colourless gum and recovered $Z$-25 (14 $\mathrm{mg}, 40 \%$ ).

An isomeric mixture of the vinylcyclopropanes 25 (22 $\mathrm{mg}$, $0.090 \mathrm{mmol} ; 87: 13, E: Z)$ in toluene $(2.6 \mathrm{~mL})$ was stirred at $40{ }^{\circ} \mathrm{C}$ for $24 \mathrm{~h}$. The mixture was concentrated under reduced pressure and the residue was purified by flash column chromatography on silica gel (petroleum ether-EtOAc, 10:1) to afford cycloheptadiene 29 (11 $\mathrm{mg}, 50 \%$ ) as a colourless gum and recovered starting material 25 (11 mg, 50\%; $74: 26, E: Z)$. $R_{\mathrm{f}}=0.45$ (petroleum ether-EtOAc, $\left.10: 1\right) ;{ }^{1} \mathrm{H}$ NMR $(400 \mathrm{MHz}$, $\left.\mathrm{C}_{6} \mathrm{D}_{6}\right) \delta 5.58(1 \mathrm{H}, \mathrm{ddd}, J=12.2,6.8,2.5 \mathrm{~Hz}), 5.43(1 \mathrm{H}, \mathrm{dd}, J=$ $12.2,2.1 \mathrm{~Hz}), 4.38-4.33$ (1H, m), 3.15-3.07 (1H, m), 2.86-2.80 (1H, m), 2.60-2.51 (1H, m), 2.46-2.35 (1H, m), $1.91(3 \mathrm{H}, \mathrm{d}, J=$ $1.4 \mathrm{~Hz}), 1.89$ (3H, s), 1.83-1.76 (1H, m), 1.61-1.53 (1H, m), 
1.29-1.19 (2H, m), 0.93 (3H, d, $J=7.0 \mathrm{~Hz}) ;{ }^{13} \mathrm{C}$ NMR (101 MHz, $\left.\mathrm{C}_{6} \mathrm{D}_{6}\right) \delta 193.3,164.0,150.7,134.3,130.6,118.7,116.9,49.8$, 41.5, 39.3, 36.1, 29.4, 29.3, 25.2, 21.4, 14.3; $\nu_{\max }$ (film) 2955, 2928, 2860, 1744, 1670, 1651, 1610, 991, 951, $717 \mathrm{~cm}^{-1}$; HMRS (ESI) calcd for $\mathrm{C}_{16} \mathrm{H}_{20} \mathrm{NaO}_{2}[\mathrm{M}+\mathrm{Na}]^{+}$267.1356, found 267.1345 .

$\left\{\left(3 \mathrm{a} S^{*}, 4 S^{*}, 7 S^{*}\right)-3 \mathrm{a}, 4,6 \mathrm{a}, 7,8,9-H e x a h y d r o-4-i s o p r o p y l-2-\right.$ methylazuleno[4,5-b]furan-3-yl\}-ethanone (30)

An isomeric mixture of the vinylcyclopropanes $26(20 \mathrm{mg}$, $0.067 \mathrm{mmol} ; 87: 13, E: Z)$ in toluene $(2.1 \mathrm{~mL})$ was stirred at $40{ }^{\circ} \mathrm{C}$ for $36 \mathrm{~h}$. The mixture was concentrated under reduced pressure and the residue was purified by flash column chromatography on silica gel (petroleum ether-EtOAc, $85: 15$ ) to afford cycloheptadiene $\mathbf{3 0}(4 \mathrm{mg}, 20 \%)$ as a colourless gum and recovered starting material $(16 \mathrm{mg}, 80 \% ; 85: 15 E: Z) . R_{\mathrm{f}}=$ 0.25 (petroleum ether-EtOAc, $85: 15) ;{ }^{1} \mathrm{H}$ NMR $(400 \mathrm{MHz}$, $\left.\mathrm{C}_{6} \mathrm{D}_{6}\right) \delta 5.65(1 \mathrm{H}, \mathrm{dd}, J=12.7,2.2 \mathrm{~Hz}), 5.57(1 \mathrm{H}, \mathrm{ddd}, J=12.7$, 6.3, 2.2 Hz), 4.47-4.41 (1H, m), 3.19-3.10 (1H, m), 3.02-2.97 (1H, m), 2.57-2.50 (1H, m), 2.35-2.23 (1H, m), $1.91(3 \mathrm{H}, \mathrm{d}, J=$ $1.3 \mathrm{~Hz}), 1.90(3 \mathrm{H}, \mathrm{s}), 1.89-1.80(2 \mathrm{H}, \mathrm{m}), 1.62-1.53(1 \mathrm{H}, \mathrm{m})$, 1.28-1.20 (2H, m), $0.94(3 \mathrm{H}, \mathrm{d}, J=7.1 \mathrm{~Hz}), 0.92(3 \mathrm{H}, \mathrm{d}, J=6.8$ $\mathrm{Hz}) ;{ }^{13} \mathrm{C}$ NMR $\left(101 \mathrm{MHz}, \mathrm{C}_{6} \mathrm{D}_{6}\right) \delta 192.0,164.8,148.5,131.9$, 127.4, 117.2, 116.8, 47.6, 43.4, 42.3, 36.6, 29.4, 29.4, 29.3, 24.8, 23.6, 19.0, 14.7; $\nu_{\max }$ (film) 2955, 2928, 2870, 2857, 1745, 1666, 1645, 1620, 986, 974, 956, 943, 918, 885, $736 \mathrm{~cm}^{-1}$; HMRS (ESI) calcd for $\mathrm{C}_{18} \mathrm{H}_{24} \mathrm{NaO}_{2}[\mathrm{M}+\mathrm{Na}]^{+}$295.1669, found 295.1656.

\section{$\left\{\left(3 \mathrm{a} S^{*}, 4 S^{*}, 7 S^{*}\right)-3 \mathrm{a}, 4,6 \mathrm{a}, 7,8,9-\mathrm{Hexahydro-2}-\mathrm{methyl-4-}\right.$} phenylazuleno[ $[4,5-b]$ furan-3-yl\}ethanone (31)

An isomeric mixture of the vinylcyclopropanes $27(60 \mathrm{mg}$, $0.20 \mathrm{mmol} ; 47: 53, E: Z)$ in toluene $(6 \mathrm{~mL})$ was stirred at $40{ }^{\circ} \mathrm{C}$ for $16 \mathrm{~h}$. The mixture was concentrated under reduced pressure and the residue was purified by flash column chromatography on silica gel (petroleum ether-EtOAc, 10:1) to afford cycloheptadiene 31 (26 mg, 43\%) as a colourless gum and recovered $Z-27$ (14 $\mathrm{mg}, 23 \%$ ).

An isomeric mixture of the vinylcyclopropanes $27(25 \mathrm{mg}$, $0.082 \mathrm{mmol} ; 70: 30, E: Z)$ in toluene $(6 \mathrm{~mL})$ was stirred at $40{ }^{\circ} \mathrm{C}$ for $24 \mathrm{~h}$. The mixture was concentrated under reduced pressure and the residue was purified by flash column chromatography on silica gel (petroleum ether-EtOAc, 10:1) to afford cycloheptadiene 31 (12 $\mathrm{mg}, 48 \%)$ as a colourless gum and recovered starting material 27 (7 mg, 28\%; 12:88, E:Z). $R_{\mathrm{f}}=0.45$ (petroleum ether-EtOAc, $\left.10: 1\right) ;{ }^{1} \mathrm{H}$ NMR $(400 \mathrm{MHz}$, $\left.\mathrm{C}_{6} \mathrm{D}_{6}\right) \delta 7.29-7.25(2 \mathrm{H}, \mathrm{m}), 7.16-7.12(2 \mathrm{H}, \mathrm{dd}, \mathrm{m}), 7.06(1 \mathrm{H}, \mathrm{tt}$, $J=7.3,1.3 \mathrm{~Hz}), 5.66(1 \mathrm{H}, \mathrm{ddd}, J=12.2,6.0,2.3 \mathrm{~Hz}), 5.61(1 \mathrm{H}$, $\mathrm{dd}, J=12.2,1.6,0.8 \mathrm{~Hz}), 4.67-4.64(1 \mathrm{H}, \mathrm{m}), 4.35(1 \mathrm{H}, \mathrm{dt}, J=$ 6.0, 3.7 Hz), 3.24-3.21 (1H, m), 2.57-2.50 (1H, m), 2.46-2.36 $(1 \mathrm{H}, \mathrm{m}), 1.93(3 \mathrm{H}, \mathrm{s}), 1.90-1.84(1 \mathrm{H}, \mathrm{m}), 1.64-1.57(1 \mathrm{H}, \mathrm{m})$, $1.47(3 \mathrm{H}, \mathrm{d}, J=1.4 \mathrm{~Hz}), 1.38-1.24(2 \mathrm{H}, \mathrm{m}) ;{ }^{13} \mathrm{C}$ NMR $(126 \mathrm{MHz}$, $\left.\mathrm{C}_{6} \mathrm{D}_{6}\right) \delta 191.9,164.6,147.8,140.9,131.0,130.0,129.8,127.9$, 126.9, 117.6, 117.3, 49.4, 44.3, 41.8, 36.5, 29.4, 29.4, 25.2, 14.4; $\nu_{\max }$ (film) 2955, 2924, 2855, 1745, 1620, 955, 760, $702 \mathrm{~cm}^{-1}$; HMRS (EI) calcd for $\mathrm{C}_{21} \mathrm{H}_{22} \mathrm{O}_{2}[\mathrm{M}]^{+}$306.1620, found 306.1623.

\section{[(E)-9-Methyl-6,8-decadien-1-yn-1-yl] trimethylsilane (33)}

To a stirred solution of isopropyltriphenylphosphonium iodide $(2.14 \mathrm{~g}, 4.95 \mathrm{mmol})$ in THF $(20 \mathrm{~mL})$ at $-10{ }^{\circ} \mathrm{C}$ was added $n$-BuLi (1.6 mL of a 2.2 M solution in hexanes, $3.5 \mathrm{mmol})$. The mixture was stirred at $-10{ }^{\circ} \mathrm{C}$ for $2 \mathrm{~h}$ and then added to a stirred solution of aldehyde (E)-8-trimethylsilyl-2-octen-7-ynal $(32)^{13}$ (534 mg, $2.75 \mathrm{mmol}$ ) in THF $(20 \mathrm{~mL})$ at $-10{ }^{\circ} \mathrm{C}$. The mixture was stirred for $1 \mathrm{~h}$ and then the reaction was quenched by addition of brine $(40 \mathrm{~mL})$. The mixture was diluted with $\mathrm{Et}_{2} \mathrm{O}(30 \mathrm{~mL})$ and the phases were separated. The aqueous phase was extracted with $\mathrm{Et}_{2} \mathrm{O}(3 \times 20 \mathrm{~mL})$. The combined organic extracts were dried over $\mathrm{MgSO}_{4}$, filtered and concentrated under reduced pressure. The residue was purified by flash column chromatography on silica gel (petroleum etherEtOAc, $300: 1)$ to afford diene 33 (501 $\mathrm{mg}, 83 \%$ ) as a pale yellow oil. $R_{\mathrm{f}}=0.43$ (petroleum ether); ${ }^{1} \mathrm{H}$ NMR $(500 \mathrm{MHz}$, $\left.\mathrm{CDCl}_{3}\right) \delta 6.24(1 \mathrm{H}, \mathrm{ddt}, J=15.0,10.8,1.3 \mathrm{~Hz}), 5.78(1 \mathrm{H}, \mathrm{d}, J=$ $10.8 \mathrm{~Hz}), 5.50(1 \mathrm{H}, \mathrm{dt}, J=15.0,7.2 \mathrm{~Hz}), 2.22(2 \mathrm{H}, \mathrm{t}, J=7.2 \mathrm{~Hz})$, $2.18(2 \mathrm{H}$, br dt $J=7.2,7.1 \mathrm{~Hz}), 1.75(3 \mathrm{H}, \mathrm{s}), 1.73(3 \mathrm{H}, \mathrm{s}), 1.60$ $(2 \mathrm{H}, \mathrm{tt}, J=7.2,7.1 \mathrm{~Hz}) 0.14(9 \mathrm{H}, \mathrm{s}) ;{ }^{13} \mathrm{C} \mathrm{NMR}\left(126 \mathrm{MHz}, \mathrm{CDCl}_{3}\right)$ $\delta$ 133.0, 130.5, 127.7, 125.1, 107.3, 84.7, 31.9, 28.5, 26.0, 19.3, 18.3, 0.3; $\nu_{\max }$ (film) 3025, 2965, 2863, 2174, 957, 839, 758, 698, $636 \mathrm{~cm}^{-1}$; HMRS (CI, isobutane) calcd for $\mathrm{C}_{14} \mathrm{H}_{25} \mathrm{Si}$ $[\mathrm{M}+\mathrm{H}]^{+}$221.1726, found 221.1726.

\section{(E)-9-Methyl-6,8-decadien-1-yne}

To a stirred solution of protected alkyne 33 (575 mg, $2.61 \mathrm{mmol})$ in $\mathrm{MeOH}(13 \mathrm{~mL})$ at rt was added $\mathrm{K}_{2} \mathrm{CO}_{3}(361 \mathrm{mg}$, $2.61 \mathrm{mmol}$ ) in one portion. The mixture was stirred for $12 \mathrm{~h}$ and then the reaction was quenched by addition of water $(20 \mathrm{~mL})$. The mixture was diluted with $\mathrm{Et}_{2} \mathrm{O}(10 \mathrm{~mL})$ and the phases were separated. The aqueous phase was extracted with $\mathrm{Et}_{2} \mathrm{O}(3 \times 5 \mathrm{~mL})$ and the combined organic extracts were dried over $\mathrm{MgSO}_{4}$, filtered and concentrated under reduced pressure. The residue was filtered through a small pad of silica gel (petroleum ether-EtOAc, $300: 1)$ to afford (E)-9-methyldeca-6,8dien-1-yne as a colourless oil. The volatile dienyne (355 mg) was used directly in the next step without further purification. $R_{\mathrm{f}}=0.33$ (petroleum ether); ${ }^{1} \mathrm{H}$ NMR $\left(400 \mathrm{MHz}, \mathrm{CDCl}_{3}\right) \delta 6.25$ (1H, ddt $J=15.0,10.8,1.2 \mathrm{~Hz}), 5.79(1 \mathrm{H}, \mathrm{d}, J=10.8 \mathrm{~Hz}), 5.51$ (1H, dt, $J=15.0,7.1 \mathrm{~Hz}), 2.24-2.16(2 \mathrm{H}, \mathrm{m}), 2.20(2 \mathrm{H}, \mathrm{m}), 1.95$ $(1 \mathrm{H}, \mathrm{t}, J=2.7 \mathrm{~Hz}), 1.76(3 \mathrm{H}, \mathrm{s}), 1.74(3 \mathrm{H}, \mathrm{s}), 1.62(2 \mathrm{H}, \mathrm{tt}, J=7.2$, $7.1 \mathrm{~Hz})$.

\section{3-[(E)-10-Methyl-7,9-undecadien-2-yn-1-ylidene]pentane-2,4- dione (35)}

To a stirred solution of (E)-9-methyl-6,8-decadien-1-yne (355 mg) in THF $(24 \mathrm{~mL})$ at $-78{ }^{\circ} \mathrm{C}$ was added $n$-BuLi $(1.6 \mathrm{~mL}$ of a $2.1 \mathrm{M}$ solution in hexanes, $3.6 \mathrm{mmol}$ ) over a period of $10 \mathrm{~min}$. The mixture was stirred at $-78{ }^{\circ} \mathrm{C}$ for $15 \mathrm{~min}$ and then anhydrous DMF (0.37 mL, $4.8 \mathrm{mmol})$ was added. The mixture was stirred at $-78{ }^{\circ} \mathrm{C}$ for a further $30 \mathrm{~min}$ and then the reaction was quenched by addition of $10 \%$ aqueous $\mathrm{KH}_{2} \mathrm{PO}_{4}$ solution $(50 \mathrm{~mL})$. The mixture was diluted with $\mathrm{Et}_{2} \mathrm{O}(20 \mathrm{~mL})$, stirred for $10 \mathrm{~min}$ and the phases were separated. The aqueous phase 
was extracted with $\mathrm{Et}_{2} \mathrm{O}(3 \times 20 \mathrm{~mL})$ and the combined organic extracts were dried over $\mathrm{MgSO}_{4}$, filtered and concentrated under reduced pressure to afford crude propargylic aldehyde 34 as a yellow oil. The reactive aldehyde was used directly in the next step without further purification. $R_{\mathrm{f}}=0.39$ (petroleum ether-EtOAc, $10: 1) ;{ }^{1} \mathrm{H}$ NMR $\left(400 \mathrm{MHz} \mathrm{CDCl}_{3}\right) \delta 9.10(1 \mathrm{H}, \mathrm{t}$, $J=0.9 \mathrm{~Hz}), 6.26(1 \mathrm{H}, \mathrm{ddt}, J=15.0,10.8,1.2 \mathrm{~Hz}), 5.78(1 \mathrm{H}, \mathrm{d}$, $J=10.8 \mathrm{~Hz}), 5.48(1 \mathrm{H}, \mathrm{dt}, J=15.0,7.1 \mathrm{~Hz}), 2.42(2 \mathrm{H}, \mathrm{td}, J=7.2$, $0.8 \mathrm{~Hz}), 2.21(2 \mathrm{H}, \mathrm{dt}, J=7.2,7.1 \mathrm{~Hz}), 1.76(3 \mathrm{H}, \mathrm{s}), 1.74(3 \mathrm{H}, \mathrm{s})$, $1.69(2 \mathrm{H}, \mathrm{tt}, J=7.2,7.2 \mathrm{~Hz})$.

To a stirred solution of crude $(E)$-10-methyl-7,9-undecadien2-ynal (34) and acetylacetone $(0.23 \mathrm{~mL}, 2.3 \mathrm{mmol})$ in toluene $(24 \mathrm{~mL})$ at $\mathrm{rt}$ were added $\mathrm{MgSO}_{4}(58 \mathrm{mg}, 0.48 \mathrm{mmol})$, piperidine $(21 \mu \mathrm{L}, 0.21 \mathrm{mmol})$, acetic acid $(0.10 \mathrm{~mL}, 1.7 \mathrm{mmol})$. The mixture was stirred at $35^{\circ} \mathrm{C}$ for $1 \mathrm{~h}$ and then the reaction was quenched by addition of water $(50 \mathrm{~mL})$. The mixture was diluted with EtOAc $(25 \mathrm{~mL})$ and the phases were separated. The aqueous phase was extracted with EtOAc $(3 \times 20 \mathrm{~mL})$ and the combined organic extracts were dried over $\mathrm{MgSO}_{4}$, filtered and concentrated under reduced pressure. The residue was purified by flash column chromatography on silica gel (petroleum ether-EtOAc, $10: 1$ ) to afford ynenedione 35 (469 mg, $70 \%$ over 3 steps) as a pale yellow oil. $R_{\mathrm{f}}=0.13$ (petroleum ether-EtOAc, $10: 1) ;{ }^{1} \mathrm{H}$ NMR $\left(400 \mathrm{MHz}, \mathrm{CDCl}_{3}\right) \delta 6.69(1 \mathrm{H}, \mathrm{t}$, $J=2.5 \mathrm{~Hz}), 6.24(1 \mathrm{H}, \mathrm{ddt}, J=15.0,10.8,1.2 \mathrm{~Hz}), 5.77(1 \mathrm{H}, \mathrm{d}, J=$ $10.8 \mathrm{~Hz}), 5.48(1 \mathrm{H}, \mathrm{dt}, J=15.0,7.2 \mathrm{~Hz}), 2.47(3 \mathrm{H}, \mathrm{s}), 2.44(2 \mathrm{H}$, $\mathrm{td}, J=7.1,2.5 \mathrm{~Hz}), 2.31(3 \mathrm{H}, \mathrm{s}), 2.18(2 \mathrm{H}, \mathrm{dtd}, J=7.2,7.1,1.2$ $\mathrm{Hz}), 1.75(3 \mathrm{H}, \mathrm{s}), 1.73(3 \mathrm{H}, \mathrm{s}), 1.65(2 \mathrm{H}, \mathrm{tt}, J=7.1,7.1 \mathrm{~Hz}) ;{ }^{13} \mathrm{C}$ NMR (101 MHz, $\left.\mathrm{CDCl}_{3}\right) \delta$ 201.4, 195.9, 149.7, 133.8, 129.8, $128.2,124.9,123.3,110.2,77.2$, 32.0, 31.1, 28.1, 27.4, 26.0, 19.8, 18.4; $\nu_{\max }$ (film) 3023, 2928, 2865, 2211, 1715, 1690, 1665, 1576, 988, $959 \mathrm{~cm}^{-1}$; HMRS (ESI) calcd for $\mathrm{C}_{17} \mathrm{H}_{22} \mathrm{NaO}_{2}$ $[\mathrm{M}+\mathrm{Na}]^{+}$281.1512, found 281.1501.

1-(5-\{(1 $\left.R^{*}, 5 S^{*}, 6 S^{*}\right)-6-(2-M e t h y l-1-p r o p e n-1-y l) b i c y c l o[3.1 .0]-h e x-$ 1-yl\}-2-methyl-3-furanyl)-ethanone (36)

Wittig alkylidenation of the aldehyde 23. To a stirred solution of isopropyltriphenyl-phosphonium iodide $(717 \mathrm{mg}$, $1.66 \mathrm{mmol})$ in THF $(30 \mathrm{~mL})$ at $-10{ }^{\circ} \mathrm{C}$ was added $n$-BuLi (1.25 mL of a $2.3 \mathrm{M}$ solution in hexanes, $2.9 \mathrm{mmol}$ ). The mixture was stirred at $-10{ }^{\circ} \mathrm{C}$ for $2 \mathrm{~h}$ and then added to a stirred solution of aldehyde 23 (193 $\mathrm{mg}, 0.831 \mathrm{mmol})$ in THF $(60 \mathrm{~mL})$ at $-10^{\circ} \mathrm{C}$. The mixture was stirred for $16 \mathrm{~h}$ at $-10^{\circ} \mathrm{C}$ and then the reaction was quenched by pouring the solution into a mixture of $\mathrm{pH} 7$ buffer $(90 \mathrm{~mL})$ and $\mathrm{Et}_{2} \mathrm{O}(40 \mathrm{~mL})$. The mixture was stirred for $10 \mathrm{~min}$ and the phases were separated. The aqueous phase was extracted with $\mathrm{Et}_{2} \mathrm{O}(3 \times 30 \mathrm{~mL})$. The combined organic extracts were dried over $\mathrm{MgSO}_{4}$, filtered and concentrated under reduced pressure. The residue was purified by flash column chromatography on aluminium oxide (activated, basic Brockmann I, petroleum ether-EtOAc, 10:1) to afford vinylcyclopropane 36 (139 mg, 65\%) as a colourless oil.

Direct acid-catalysed cyclisation of ynenedione 35 . To a stirred solution of ynenedione $35(42 \mathrm{mg}, 0.16 \mathrm{mmol})$ in $\mathrm{CH}_{2} \mathrm{Cl}_{2}(0.60 \mathrm{~mL})$ at $\mathrm{rt}$ was added chloroacetic acid $(15 \mathrm{mg}$, $0.16 \mathrm{mmol}$ ) in one portion. The mixture was stirred at $40{ }^{\circ} \mathrm{C}$ for $24 \mathrm{~h}$ and then concentrated under reduced pressure. The residue was purified by flash column chromatography on silica gel (petroleum ether-EtOAc, $10: 1$ ) to afford vinylcyclopropane $36(25 \mathrm{mg}, 59 \%)$ as a colourless oil. $R_{\mathrm{f}}=0.48$ (petroleum ether-EtOAc, $10: 1) ;{ }^{1} \mathrm{H}$ NMR (400 MHz, $\left.\mathrm{C}_{6} \mathrm{D}_{6}\right) \delta 6.19(1 \mathrm{H}, \mathrm{s})$, $4.98(1 \mathrm{H}, \mathrm{dqq}, J=8.7,1.3,1.2 \mathrm{~Hz}), 2.38(3 \mathrm{H}, \mathrm{s}), 2.13(1 \mathrm{H}, \mathrm{dd}$, $J=12.4,8.4,0.6 \mathrm{~Hz}), 2.01(3 \mathrm{H}, \mathrm{s}), 1.91(1 \mathrm{H}, \mathrm{ddd}, J=12.4,11.4$, $8.4 \mathrm{~Hz}), 1.81(1 \mathrm{H}, \mathrm{dd}, J=8.7,4.1 \mathrm{~Hz}), 1.76-1.71(2 \mathrm{H}, \mathrm{m})$, 1.69-1.65 (1H, m), $1.64(3 \mathrm{H}, \mathrm{d}, J=1.2 \mathrm{~Hz}), 1.59(3 \mathrm{H}, \mathrm{d}, J=$ $1.3 \mathrm{~Hz}), 1.55-1.46(1 \mathrm{H}, \mathrm{m}), 1.27-1.12(1 \mathrm{H}, \mathrm{m}) ;{ }^{13} \mathrm{C}$ NMR $\left(101 \mathrm{MHz}, \mathrm{C}_{6} \mathrm{D}_{6}\right) \delta 192.6,156.6,154.9,132.1,123.3,122.6$, 106.7, 33.3, 33.1, 33.0, 28.8, 27.9, 25.8, 25.7, 22.2, 18.5, 14.3; $\nu_{\max }$ (film) 3025, 2959, 2926, 2864, 1677, 1570, 949, $635 \mathrm{~cm}^{-1}$; HMRS (ESI) calcd for $\mathrm{C}_{17} \mathrm{H}_{22} \mathrm{NaO}_{2}[\mathrm{M}+\mathrm{Na}]^{+} 281.1512$, found 281.1499.

$\left\{\left(3 \mathrm{a} S^{*}, 7 S^{*}\right)-3 \mathrm{a}, 4,6 \mathrm{a}, 7,8,9-H e x a h y d r o-2,4,4-t r i m e t h y l a z u l e n o[4,5-\right.$ b] furan-3-yl\}ethanone (37)

A solution of vinylcyclopropane $36(48 \mathrm{mg}, 0.19 \mathrm{mmol})$ in toluene $(4 \mathrm{~mL})$ was stirred at $110{ }^{\circ} \mathrm{C}$ for $16 \mathrm{~h}$. The mixture was concentrated under reduced pressure and the residue was purified by flash column chromatography on silica gel (petroleum ether-EtOAc, $10: 1$ ) to afford cycloheptadiene 37 (13 mg, 27\%, $68 \% \mathrm{brsm}$ ) as a colourless gum. $R_{\mathrm{f}}=0.45$ (petroleum etherEtOAc, $10: 1$ ); ${ }^{1} \mathrm{H}$ NMR (400 MHz, $\left.\mathrm{C}_{6} \mathrm{D}_{6}\right) \delta 5.36(1 \mathrm{H}, \mathrm{dd}, J=$ 12.3, $2.0 \mathrm{~Hz}$ ), 5.27 (1H, dd, $J=12.3,2.5 \mathrm{~Hz}), 4.20-4.18(1 \mathrm{H}, \mathrm{br})$, 3.14-3.06 (1H, m), 2.59-2.50 (1H, m), 2.44-2.33 (1H, m), 1.95 $(3 \mathrm{H}, \mathrm{d}, J=1.3 \mathrm{~Hz}), 1.94(3 \mathrm{H}, \mathrm{s}), 1.86-1.77(1 \mathrm{H}, \mathrm{m}), 1.61-1.54$ (1H, m), 1.33-1.16 (2H, m), 1.01 (3H, s), 0.95 (3H, s); ${ }^{13} \mathrm{C}$ NMR $\left(101 \mathrm{MHz}, \mathrm{C}_{6} \mathrm{D}_{6}\right) \delta 193.6,164.0,149.3,139.4,128.6,117.6$, 117.1, 53.0, 41.1, 38.6, 36.2, 30.2, 29.3, 29.2, 25.3, 24.2, 14.1; $\nu_{\max }$ (film) 2955, 2928, 2863, 1744, 1668, 1652, 1609, 949, $729 \mathrm{~cm}^{-1}$; HMRS (ESI) calcd for $\mathrm{C}_{17} \mathrm{H}_{22} \mathrm{NaO}_{2}[\mathrm{M}+\mathrm{Na}]^{+}$ 281.1512, found 281.1501.

\section{Conflicts of interest}

There are no conflicts to declare.

\section{Acknowledgements}

The authors thank the University of Glasgow for studentship funding for VK and a postdoctoral fellowship for SW.

\section{Notes and references}

1 J. B. Sperry and D. L. Wright, Curr. Opin. Drug Discovery Dev., 2005, 8, 713.

2 (a) H. Hikino and C. Konno, Heterocycles, 1976, 4, 817; (b) R. Maurya and P. P. Yadav, Nat. Prod. Rep., 2005, 22, 400; (c) Y. Liu, S. Zhang and P. J. M. Abreu, Nat. Prod. Rep., 2006, 23, 630; (d) P. A. Roethle and D. Trauner, Nat. Prod. Rep., 2008, 25, 298; (e) S. O. Simonetti, E. L. Larghi, 
A. B. Bracca and T. S. Kaufman, Nat. Prod. Rep., 2013, 30, 941.

3 J. Xu, Y. Guo, Y. Li, P. Zhao, C. Liu, Y. Ma, J. Gao, W. Hou and T. Zhang, Planta Med., 2011, 77, 2023.

4 A. D. Patil, A. J. Freyer, L. Killmer, P. Offen, B. Carte, A. J. Jurewicz and R. K. Johnson, Tetrahedron, 1997, 53, 5047.

5 F. Marion, D. E. Williams, B. O. Patrick, I. Hollander, R. Mallon, S. C. Kim, D. M. Roll, L. Feldberg, R. Van Soest and R. J. Andersen, Org. Lett., 2006, 8, 321.

6 J. S. Clark, F. Romiti, K. F. Hogg, M. H. S. A. Hamid, S. C. Richter, A. Boyer, J. C. Redman and L. J. Farrugia, Angew. Chem., Int. Ed., 2015, 54, 5744.

7 G. Pattenden and J. M. Winne, Tetrahedron Lett., 2009, 50, 7310.

8 J. M. Winne, S. Catak, M. Waroquier and V. Van Speybroeck, Angew. Chem., Int. Ed., 2011, 50, 11990.

9 B. Song, L.-H. Li, X.-R. Song, Y.-F. Qiu, M.-J. Zhong, P.-X. Zhou and Y.-M. Liang, Chem. - Eur. J., 2014, 20, 5910.
10 (a) S. Mata, L. A. López and R. Vicente, Synlett, 2015, 26852689; (b) S. Mata, J. González, R. Vicente and L. A. López, Eur. J. Org. Chem., 2016, 2681.

11 G. Maas and C. Hummel, Chem. Ber., 1980, 113, 3679.

12 J. Barluenga, F. Aznar, I. Gutiérrez and J. A. Martín, Org. Lett., 2002, 4, 2719.

13 M. Goto, I. Miyoshi, Y. Ishii, Y. Ogasawara, Y.-I. Kakimoto, S. Nagumo, A. Nishida, N. Kawahara and M. Nishida, Tetrahedron, 2002, 58, 2339.

14 (a) K. G. R. Pachler, J. Chem. Soc., Perkin Trans. 2, 1972, 1936; (b) C. A. G. Haasnoot, F. A. A. M. de Leeuw and C. Altona, Tetrahedron, 1980, 36, 2783.

15 S. Krüger and T. Gaich, Beilstein J. Org. Chem., 2014, 10, 163.

16 T. Shen, C. W. Weng, W. D. Xie and K. H. Row, J. Chem. Res., 2009, 33, 623.

17 W. Vichnewski and B. Gilbert, Phytochemistry, 1972, 11, 2563. 